\title{
Detecting inundation thresholds for dryland wetland vulnerability
}

\author{
Steven G. Sandi ${ }^{\text {a }}$, Patricia M. Saco ${ }^{\mathrm{a}}$, Neil Saintilan ${ }^{\mathrm{b}}$, Li Wen ${ }^{\mathrm{c}}$, Gerardo Riccardi ${ }^{\mathrm{d}}$, \\ George Kuczera ${ }^{a}$, Garry Willgoose ${ }^{a}$, José F. Rodríguez ${ }^{\text {a,* }}$ \\ ${ }^{a}$ Centre for Water Security and Environmental Sustainability and School of Engineering, The University of Newcastle, Callaghan 2308, Australia \\ ${ }^{\mathrm{b}}$ Department of Environmental Sciences, Macquarie University, North Ryde 2109, Australia \\ ' Science Division, NSW Office of Environment and Heritage, Sydney 2000, Australia \\ ${ }^{\mathrm{d}}$ Department of Hydraulics and Research Council of National University of Rosario (CIUNR), Rosario 2000, Argentina
}

\section{A R T I C L E I N F O}

\section{Keywords:}

Dryland wetlands

Inundation modelling

Seasonal fractional cover

Minimum inundation requirements

River red gum

Terrestrial vegetation invasion

Macquarie Marshes

\begin{abstract}
A B S T R A C T
Dryland wetlands receiving periodical floods are of key importance for ecological resilience. The inundation regime (i.e., frequency, duration, depth, and timing of inundation), is one of the major factors that determine the suitability of local conditions for specific wetland species. During droughts, inundation conditions can reach a threshold after which wetland vegetation could transition to dryland vegetation. This study analyses the response of vegetation to hydrologic variability in an arid wetland in Australia over a period of 22 years (including the Millennium drought) in order to identify inundation thresholds for transitions. We use numerical modelling, field observations and remote sensing data to relate continuous detailed simulations of the inundation regime with the response of patches of Common reed, Water couch and River red gum, three key vegetation associations in the study site. We focus in patches that were affected by the drought and presented dryland vegetation invasion as well as reference patches that remained healthy throughout the drought. On each patch, we compare annual and inter-annual simulated inundation regimes to the minimum inundation conditions that can support the specific vegetation, and we compute the percentage area of the patch that verifies minimum inundation for each year. We define this area percentage as minimum inundation index. This index is analysed in conjunction with Landsat derived information on green vegetation coverage (green Seasonal Fractional Cover) for the selected patches. We found that the minimum inundation index and inter annual frequency are able to describe the vegetation dynamics of the patches, which can be characterised by two distinct response modes that depend on a threshold value of the minimum inundation index. Inundation below the threshold noticeably leads to degraded vegetation, but the vegetation can recover quickly if this threshold is later maintained for one or two years. Values below the threshold for more extended periods (drought) result in a gradual decrease of wetland vegetation to almost complete disappearance after four years and subsequent dryland vegetation invasion.
\end{abstract}

\section{Introduction}

Dryland wetlands receiving periodical floods are of key importance for regional ecological resilience (Leigh et al., 2010). These periodical floods result from upstream inflows that interact with the local lowland geomorphology and generate a complex network of channels and distributaries, lagoons, and swamps (Tooth and McCarthy, 2007; Ralph and Hesse, 2010; Larkin et al., 2017). Floods deliver sediment and nutrients to the floodplain, allow aquatic fish and invertebrates to reach floodplain environments or distant waterholes, and trigger important processes for the life cycle of some species such as waterbird breeding episodes (Leigh et al., 2010). During dry periods, perennial water sites serve as habitat sanctuaries for many species of aquatic biota
(Sheldon et al., 2010). These habitats include stream and groundwater areas, as well as riparian or floodplain vegetated areas which are essential for the survival of the fauna.

Vegetation maintenance and survival in dryland floodplains are tightly coupled to the inundation regime. The frequency, duration, depth, and timing of inundation determine the suitability of local conditions to sustain specific plant species (Rogers, 2011; Roberts and Marston, 2011). Consequently, the inundation regime establishes a gradient of conditions for vegetation establishment across the floodplain (Brock and Casanova, 1997; Stromberg et al., 2010; Rogers, 2011), which is influenced by local surface water dynamics and floodplain hydrological connectivity (Thoms, 2003; Thoms and Parsons, 2003; Murray et al., 2006; Keesstra et al., 2018; Saco et al., 2018). This spatial

\footnotetext{
* Corresponding author.

E-mail address: jose.rodriguez@newcastle.edu.au (J.F. Rodríguez).
} 
variability in flow and inundation conditions gives rise to a mosaic-like distribution of habitats suitable for different plant species (Ward et al., 1999; Capon, 2003; Puckridge et al., 2010; Murray-Hudson et al., 2014; Bishop-Taylor et al., 2017).

Recent modelling efforts have linked the inundation regime to vegetation distribution and condition in order to predict wetland response to future climate and the effect of potential management strategies (Foti et al., 2012; Saco and Rodríguez, 2013; Tan and Jiang, 2016; Tan et al., 2016; Rodríguez et al., 2017; Sandi et al., 2018). In arid wetlands, a key step for the simulation of the vegetation response to changing inundation regimes is the identification of threshold conditions for vegetation transitions. A transition occurs when local conditions are no longer suitable for a given plant species (e.g., wetland species) and become suitable for another encroaching species (e.g., dryland plants). The identification of threshold conditions becomes critically important for drought periods when wetland areas may be lost. Vegetation transitions in dryland wetlands are mainly influenced by the preferred inundation regime, but they may also be influenced by other factors like salinity, turbidity, and seedbank establishment (Porter et al., 2007), as well as bushfires (Bino et al., 2015) or, in some areas, the presence of groundwater springs (Fensham et al., 2004). Additionally, transitions are affected by the resilience of dryland wetland plants species to extended dry periods (Capon and Reid, 2016). Consequently, in order to identify conditions for vegetation transition to use in models of dryland wetland dynamics, it is necessary to simultaneously analyse the inundation regime and the vegetation status over a long enough period of time, with suitable spatial and temporal resolutions.

The availability of field data from dryland wetland vegetation surveys is usually limited and therefore inadequate to describe the dynamics of vegetation over the spatial and temporal scales required to obtain transition relations. This limitation can be partially overcome with the use of remotely sensed data to assess vegetation distribution (Lawley et al., 2016). Remote sensing products have also been used to analyse vegetation with the use of vegetation indicators such as the normalized difference vegetation index (NDVI) (Wen et al., 2012; Andela et al., 2013; Cui et al., 2013; Whitaker et al., 2015), enhanced vegetation index (EVI) (Karnieli et al., 2013; Andela et al., 2013), fraction of photosynthetically active radiation absorbed by the canopy (FPAR) (Wang et al., 2015) and vegetation fractional cover (Guerschman et al., 2009; Guerschman et al., 2015). Use of this type of indicators may be limited by data availability for a particular region and the quality of the remotely sensed data.

Remote sensing data have also been used to characterise wetland inundation regimes and relate them to vegetation health and wetland function (Thomas et al., 2010; Thomas et al., 2011; Wang et al., 2015; Murray-Hudson et al., 2015; Ren and Kingsford, 2011). Empirical probabilistic vegetation transition functions have been proposed using inundation maps derived from remotely sensed information (Bino et al., 2015). However, the resulting relations are heavily constrained by the availability of remote sensing data on inundation required at different time scales, and the information provided may not be enough to describe all the characteristics of the inundation regime relevant for vegetation. For example, water depth is an important characteristic of the inundation regime that cannot be obtained from remotely sensed data. Alternatively, remote sensing data on inundation can be used to develop and calibrate hydrodynamic inundation models (Heimhuber et al., 2017), which are able to describe the inundation regime in detail and can be combined with information on vegetation dynamics and distribution at a variety of scales. Process-based transition functions can then be derived to directly link the inundation regime to the vegetation response.

Here we use numerical modelling, field surveys and remote sensing data to show that changes observed in vegetation of an Australian dryland wetland over a period of 22 years (1991-2013) consistently responded to the inundation regime both at the annual and inter-annual time scale. We quantify this response in terms of process-based transi- tion thresholds for a number of vegetation associations by combining simulations of the spatially variable inundation regime experienced by each vegetation association with remotely sensed information on vegetation distribution and status. We follow changes in the vegetation of the dryland wetlands as it deteriorated during one of the worst droughts on record (the Millenium drought) and as it recovered afterward, clearly identifying conditions for vegetation transition. The transition thresholds obtained from our analysis have the potential to predict shifts from wetland vegetation to terrestrial vegetation in the future under different climate conditions and also in other wetlands with similar vegetation distribution.

\section{Study site}

The Macquarie Marshes date back thousands of years (Yonge and Hesse, 2009) and have been an important settlement for the Wailwan Aboriginal people, holding cultural and spiritual significance and providing a regular source of food and water (Masman and Johnstone, 2000). After European colonization, cattle stations and agriculture were established in the region since the 1830's (Masman and Johnstone, 2000). Large-scale irrigated agriculture impacted the site after the construction of the Burrrengdon dam upstream of the marshes in 1967 (Kingsford, 2000), but concerns about the effects of human intervention predate the construction of the dam. Since the early 1900's, areas of the Macquarie Marshes have been protected to be used as a sanctuary for native fauna (Berney and Hosking, 2016).

The study focuses on the Northern Marshes of the Macquarie Marshes, one of the key lowland floodplain wetland systems in northwestern New South Wales, Australia (Fig. 1a). This wetland system is a complex collection of interconnected marshes, swamps, lagoons and anabranching channels featuring distinct vegetation patches. The Ramsar-listed marshes have unique ecological value, supporting a wide variety of flood-dependent flora and fauna that include forests and woodlands, grasslands, reed beds, shrublands and sedge-lands (Bowen and Simpson, 2010; Bowen et al., 2017), at least 52 species of waterbirds (Rogers et al., 2010), and many species of fish and frogs (Rogers et al., 2010).

Mean annual rainfall in the Macquarie Marshes ranges from 400 to $500 \mathrm{~mm}$, while evapotranspiration can reach values between 1500 and $2000 \mathrm{~mm}$ per year (Ralph and Hesse, 2010). This water balance deficit is typical of semiarid climates where the vegetation becomes dependent on floods produced by upstream catchment areas. Flooding in the Macquarie Marshes occurs mainly due to incoming discharges released from Burrendong Dam. Most of the discharge that reaches the Northern Marshes is recorded at a gauging station located at Pillicawarrina (station No.421147) (Fig. 1b) with a mean annual discharge of $526 \mathrm{ML} /$ day $\left(6.08 \mathrm{~m}^{3} / \mathrm{s}\right)$, and a mean annual runoff volume of $191990 \mathrm{ML}$. Flows in the Macquarie River are not only irregular on a monthly scale (seasonal), but also on an interannual and interdecadal scales due to El Niño Southern Oscillation (ENSO) (Ralph and Hesse, 2010). Additionally, flows in the reach from the Burrendong dam to the marshes are affected by diversions for agricultural and domestic purposes via control structures such as weirs, regulators, bypass canals, earthen embankments, irrigation channels and pumping (Ralph and Hesse, 2010; Steinfeld and Kingsford, 2013), which adds to water deficits in the wetlands.

Vegetation in the site has growing seasons between spring, summer and autumn, and little to no growth occurs during winter (Roberts and Marston, 2011). Most of the vegetation in the Macquarie Marshes can be classified as intensive users of water because they develop shallow root networks in order to access moisture in the soil (Rodríguez-Iturbe and Porporato, 2007). Due to rainfall deficit in the region, moisture recharge used by the vegetation depends on overbank floods produced by runoff originated upstream in the catchment. Inundation, therefore, is extremely important for the survival and maintenance of the vegetation, and the spatial distribution of the inundation regime helps maintain the heterogeneity of the wetland (Wen et al., 2012). 


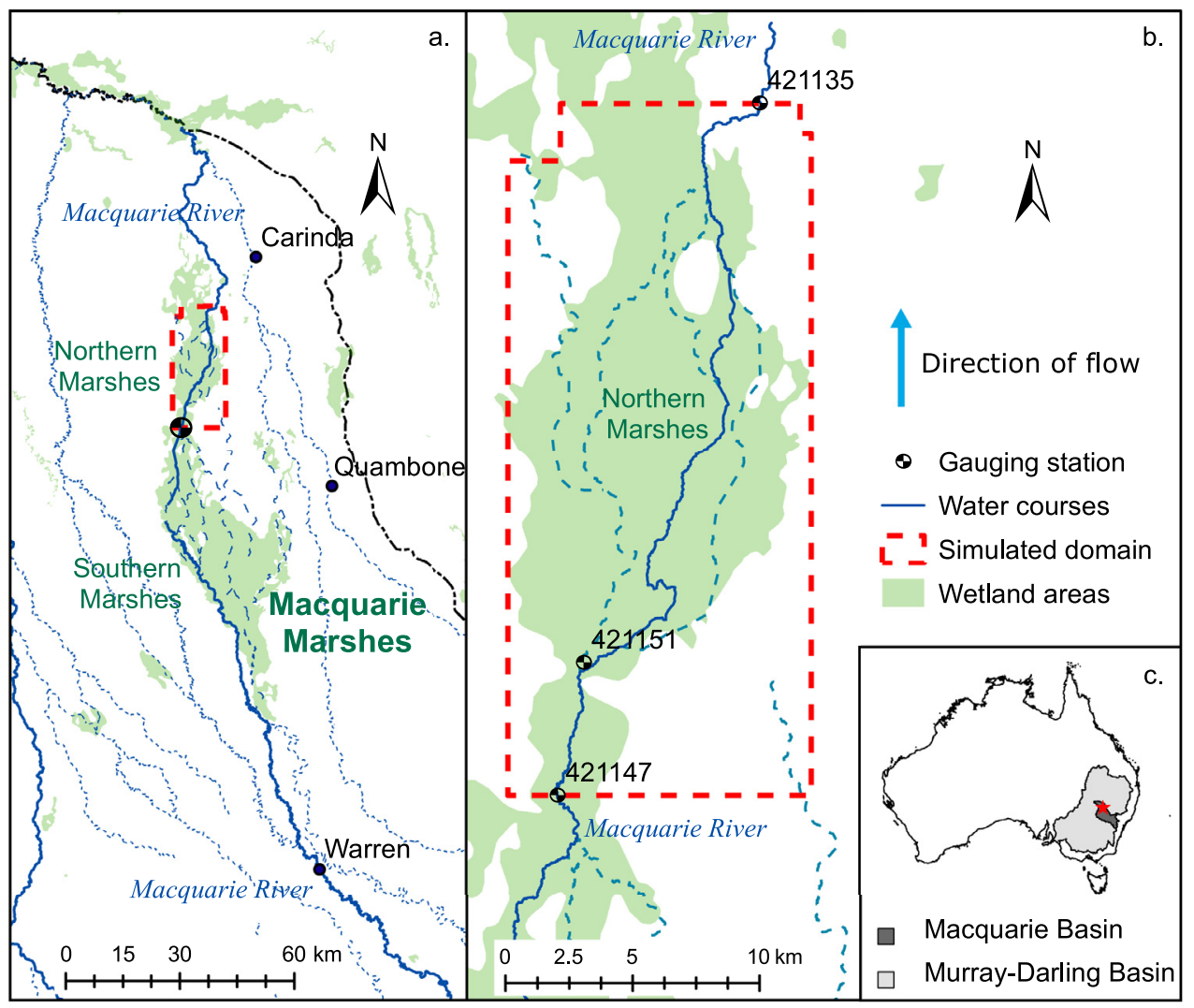

Fig. 1. (a) The Macquarie Marshes, (b) Study site: the Northern Marshes, (c) Location of the Macquarie Marshes.
Historical wetland degradation in the Macquarie Marshes has been largely attributed to water diversions for agricultural use, which translated into a decrease of flooding extent and frequency (Kingsford, 2000). This has had a major impact on the flood-dependent vegetation. Between 1991 and 2008, many wetland areas experienced terrestrial vegetation encroachment (Bowen and Simpson, 2010) mainly due to changes in inundation patterns (Thomas et al., 2010; Thomas et al., 2011). These conditions worsened during the Millennium Drought, a drought period that affected Australia between 1996 and 2009. Immediately after the break of drought in 2010, the conditions of the wetland improved, but some areas did not totally recover due to the time it took for terrestrial vegetation to retreat from wetland areas (Thomas et al., 2010). After a series of record-breaking rainfalls in the upper catchment, and the use of adaptive water management strategies, an important improvement of the wetland vegetation condition and extent was evident by 2013 (Bowen and Simpson, 2013; Bowen et al., 2017).

\section{Methodology}

Our approach not only considers that the inundation regime provides the conditions for vegetation survival, but also accounts for the resilience of dryland wetland vegetation that can withstand unfavourable conditions for relatively extended droughts. In order to fully incorporate the effect of the inundation regime, both in space and time, we use continuous simulations of a two-dimensional hydrodynamic model (Fig. 2). This approach allows us to overcome limitations imposed by a lack of information at the required temporal and spatial scales, which is a typical problem in observation-based approaches.

To capture the response of wetland vegetation to changes in the inundation regime, we first identify vegetation patches that are representative of the main vegetation associations of the wetland. We follow the vegetation health conditions in these patches using satellite information (Fig. 2) over a period of 22 years (1991-2013) that includes one of the worst droughts on record. We select patches considerably affected by the drought as well as reference patches that remained healthy over the entire period. We then assess the inundation regime for all patches over the period of analysis using the hydrodynamic model in order to compare the inundation regime of healthy and degraded patches. The proportion of the patch that satisfies the minimum inundation conditions, as reported in the literature for various vegetation associations, is then estimated and used to compute vegetation transition thresholds (Fig. 2).

\subsection{Hydrodynamic model description and setup}

In order to quantify the inundation conditions that affected vegetation at different locations in the Northern Marshes during the 22-year period (1991-2013), we use a hydrodynamic model that has been successfully applied to flatlands (Riccardi, 2000), floodplains (Basile et al., 2010; Sandi-Rojas et al., 2014; Garcia et al., 2015; Stenta et al., 2017), and estuarine wetlands (Rodríguez et al., 2017; Sandi et al., 2018). The model is based on a spatially distributed cells scheme first proposed by Cunge (1975) and solves multidirectional hydrologic and hydraulic relations between cells using a finite differences method.

Model domain is classified as floodplain cells or river cells. River cells containing a channel and the adjacent floodplain within the cell. Full dynamic equations are used for channel flow, but for slow floodplain flow, in which inertial effects can be neglected, a diffusive wave simplification is used (Riccardi, 2000). The model domain is discretised into a $90 \times 90 \mathrm{~m}$ grid, with a total of 40096 cells. This grid size is comparable with similar floodplain flow simulations (Wen et al., 2013), and was obtained from resampling a $1 \mathrm{~m}$ resolution LiDAR Digital Elevation Model (DEM) acquired during a very dry period in which vegetation interference was minimum. The river network is represented by 724 river cells, whose geometric characteristics were obtained by complementing the original $1 \mathrm{~m}$ resolution LiDAR DEM with more detailed topographical surveys. Final adjustments to the DEM in inaccessible wetland areas where vegetation coverage interfered with the LiDAR measurements 


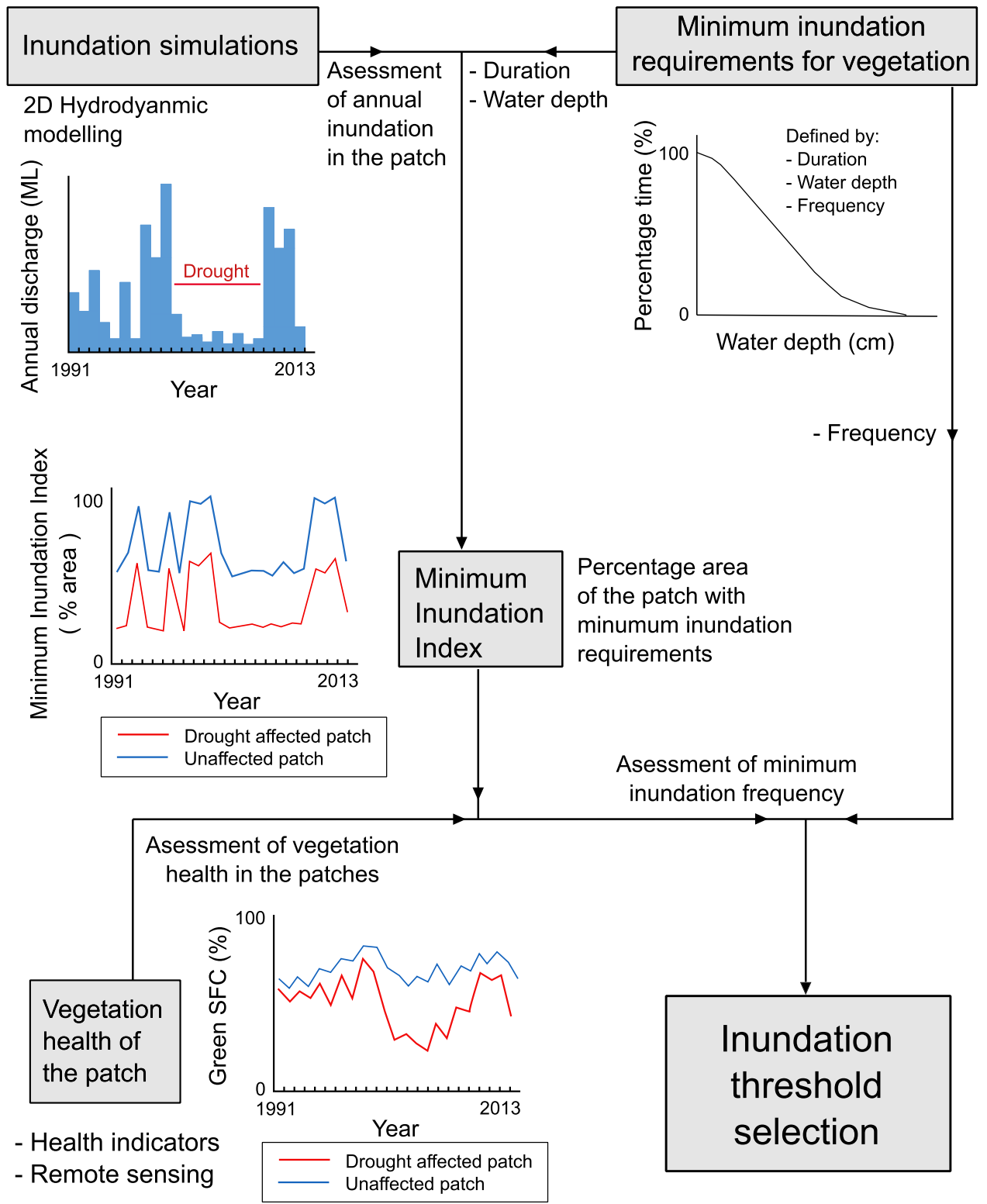

Fig. 2. Methodology scheme for obtaining inundation thresholds. (permanent reed beds) were carried out so that the general flow patterns of preliminary runs of the hydrodynamic model matched observations from inundation maps.

Three types of boundary conditions were incorporated in the hydrodynamic model. The upstream boundary condition consisted of river flows at gauging station No.421147 (Fig. 1b), where entrance flows are concentrated in the Macquarie River. For the downstream boundary conditions we used the water levels recorded at station No.421135 (Fig. 1b) in the Macquarie River and we also assumed the same level over the cells on the northern boundary of the domain, to represent the diffused floodplain flow observed. All other boundary conditions were set as no-flow.

The model solves mass conservation with a fully two-dimensional framework and then solves the momentum conservation at the links between cells using simplified one-dimensional formulations. Different approximations are used to handle water transfer between two river cells, between two floodplain cells and between river and floodplain cells. Specific formulations are also used for flow across culverts and weirs, as presented in (Riccardi, 2000; Rodríguez et al., 2017; Sandi et al., 2018). The differential equation system is solved with the Gauss-Seidel iterative method and model stability is assured with the Courant-Friedrichs-Lewy condition.
Because of the small time steps of the model (due to stability conditions), the large size of the domain (40 096 cells) and the extended length of our simulations (22 years), processes like infiltration, local rainfall and evapotranspiration are not included. The magnitude of these processes is small compared to the volumes delivered by the dam and their simulation is computationally demanding. Moreover, the limited available information on these variables incorporates uncertainties in the model and complicates calibration and model testing. We found that the exclusion of these processes do not affect the performance of our model when compared to a conventional model with built-in modules for infiltration and evapotranspiration (Sandi-Rojas et al., 2014).

\subsection{Hydrodynamic model calibration and testing}

The Manning roughness coefficients $(n)$ for the different vegetation associations was calibrated to adequately recreate observed water depths recorded at gauging station No.421151 and inundation patterns obtained from Landsat images (Thomas et al., 2010; Thomas et al., 2011). For floodplain elements, initial roughness values were determined using Cowan's method (Green, 2005; Arcement and Schneider, 1989) and by comparison with roughness values implemented by Wen et al. (2013). Final values of Manning's roughness are presented 
Table 1

Calibrated roughness values for each vegetation association in the study area.

\begin{tabular}{ll}
\hline Land use and vegetation association & $\mathrm{n}\left[\mathrm{s} \cdot \mathrm{m}^{-1 / 3}\right]$ \\
Channels & 0.035 (clean) -0.1 (vegetated) \\
\hline Floodplain & \\
Cultivated & 0.05 \\
Terrestrial & 0.036 \\
Floodplain vegetation & 0.053 \\
River red gum association & 0.07 \\
Lignum & 0.11 \\
Water couch & 0.075 \\
Mixed marsh & 0.057 \\
Common reeds & 0.11 \\
\hline
\end{tabular}

in Table 1. For channels and streams, Manning's roughness values were tested in the range from $0.035 \mathrm{~s} \bullet \mathrm{m}^{-1 / 3}$ to $0.10 \mathrm{~s} \bullet \mathrm{m}^{-1 / 3}$ depending on the conditions of the river reach (vegetated, well-defined channels, shallow channels).

Six different flow events were selected between 1991 and 2013 for calibration and model testing. The events were selected based on the availability of remotely sensed inundation maps comparison, and the quality of the data recorded at station No.421151. For calibration, we used the events from 1999, 2011 and 2013 while the events from 1993, 2000 and 2010 were used for model testing. The hydrodynamic model performance based on water level recorded at station No.421151 was assessed using three statistical indicators (Moriasi et al., 2007): percent bias (PBIAS), Nash-Sutcliffe coefficient (NS) and the ratio of the root mean square error to the standard deviation of measured data (RSR). Excellent performance of the model is achieved when $-10 \%$ < PBIAS $<10 \%$, NSE $>0.75$, and RSR $<0.50$ (Moriasi et al., 2007). Model results show excellent performance both for calibration and testing events (Table 2 and Fig. 3).

Visual comparison of model inundation predictions with inundation maps showed a generally good representation for the different flow events. Fig. 4 illustrates selected simulated flow inundation patterns during calibration, which have a similar degree of agreement observed during model testing. Even though the inundation patterns show some discrepancies with Landsat derived inundation maps, our results are comparable with previous inundation extent estimates using a hydrodynamic model in this system (Wen et al., 2013). The estimated overall accuracy (Congalton, 1991) of the model compared to Landsat derived inundation maps varies from 0.77 to 0.81 (Table 3). This level of accuracy is remarkably good considering that the overall accuracy of the Landsat derived inundation maps for the marshes ranges from 0.79 to 0.95 (Thomas et al., 2015). Cohen's $\kappa$ statistic was around 0.6, similarly to the values reported by Chen et al. (2013) for inundation maps in wetlands of the Murray Darling Basin.

\subsection{Vegetation classification and selection of patches}

In order to select patches that are representative of the vegetation distribution of the wetland and also contain information on transitions, we use existing vegetation maps for 1991, 2008 and 2013 (Wilson, 1992;
Table 3

Performance indicators of simulated inundation extent.

\begin{tabular}{llllll}
\hline Index & 1993 event & 1999 event & 2000 event & 2010 event & 2011 event \\
\hline Overall accuracy & 0.80 & 0.81 & 0.77 & 0.80 & 0.80 \\
Cohen's $\kappa$ & 0.60 & 0.59 & 0.54 & 0.59 & 0.59 \\
\hline
\end{tabular}

Note: the 2013 event was excluded due to the low quality of the Landsat images.

Bowen and Simpson, 2009, 2013; Bowen et al., 2017). These maps also contain critical information on transitions and health conditions needed for this study. These maps were derived using a combination of aerial photography interpretation and ground survey, providing snapshots of the vegetation distribution and status at critical time points (Fig. 6). The 1991 survey was carried out after several years of wet conditions, so the wetland displayed a reasonably healthy vegetation at the beginning of our period of analysis. The 2008 survey coincides with the end phase of the Millennium Drought and constitutes a good indicator of the system under stress, with many wetland vegetation patches transitioned to terrestrial vegetation. The 2013 survey was conducted after a wet period and reflected signs of vegetation recovery.

The vegetation maps contain 16 different vegetation types. It is difficult to link all vegetation types to inundation requirements. Consequently, we aggregated the 16 vegetation types based on similar inundation requirements following Roberts and Marston (2011) and Rogers (2011). Not all associations were affected to the same extent by the drought, so we concentrated our analysis on areas where we could clearly identify signs of transition or deterioration. We selected different patches of relatively homogeneous vegetation both within those areas and in areas less affected by the drought for comparison. For each vegetation association we defined minimum inundation conditions associated with vegetation maintenance/health in terms of depth, duration and frequency based on previous research (Roberts and Marston, 2011; Rogers, 2011). Using these values, we compute the area fraction (\% patch area) for each patch that meets the minimum inundation conditions according to the hydrodynamic model results, and define that area fraction as the minimum inundation index for the assessment and prediction of wetland vegetation health.

\subsection{Indicators of wetland vegetation dynamics and health}

As previously mentioned, the vegetation maps of 1991, 2008 and 2013 provide snapshots of the vegetation distribution and status before and after wet and dry periods. However, they do not provide a continuous indicator of the wetland health needed to understand the relation between vegetation health and inundation conditions. Wetland vegetation can respond to changes in inundation conditions at much shorter timescales than the interval between vegetation maps (e.g. reeds can substantially recover on the first flood event after a drought) (Roberts and Marston, 2011). A shorter time scale is therefore required to capture the effects of inundation regime on vegetation dynamics and to be able to clearly pinpoint the transitions and identify inundation threshold values. This shorter time scale information can be derived from satellite data, in our case Landsat derived products due to spatial

Table 2

Performance of the model for six different events recorded at station no. 421151.

\begin{tabular}{lllllll}
\hline Index & $\begin{array}{l}1993 \text { event } \\
\mathrm{N}^{* *}=66\end{array}$ & $\begin{array}{l}\text { 1999 event } \\
N=69 \text { Calibration }\end{array}$ & $\begin{array}{l}2000 \text { event } \\
N=87\end{array}$ & $\begin{array}{l}2010 \text { event } \\
N=127 \text { Calibration }\end{array}$ & $\begin{array}{l}2011 \text { event } \\
N=138 \text { Calibration }\end{array}$ & $\begin{array}{l}2013 \text { event } \\
N=149\end{array}$ \\
\hline PBIAS (\%) & 10.0 & -0.3 & 5.6 & 5.6 & 3.3 & -2.1 \\
NS & 0.99 & 1.00 & 0.99 & 0.98 & 0.98 & 0.90 \\
RSR & 0.10 & 0.03 & 0.07 & 0.13 & 0.13 & 0.32 \\
\hline
\end{tabular}

Note:

* A negative PBIAS means overestimation and a positive PBIAS means underestimation.

** $\mathrm{N}$ represents the number of days considered in each event. 

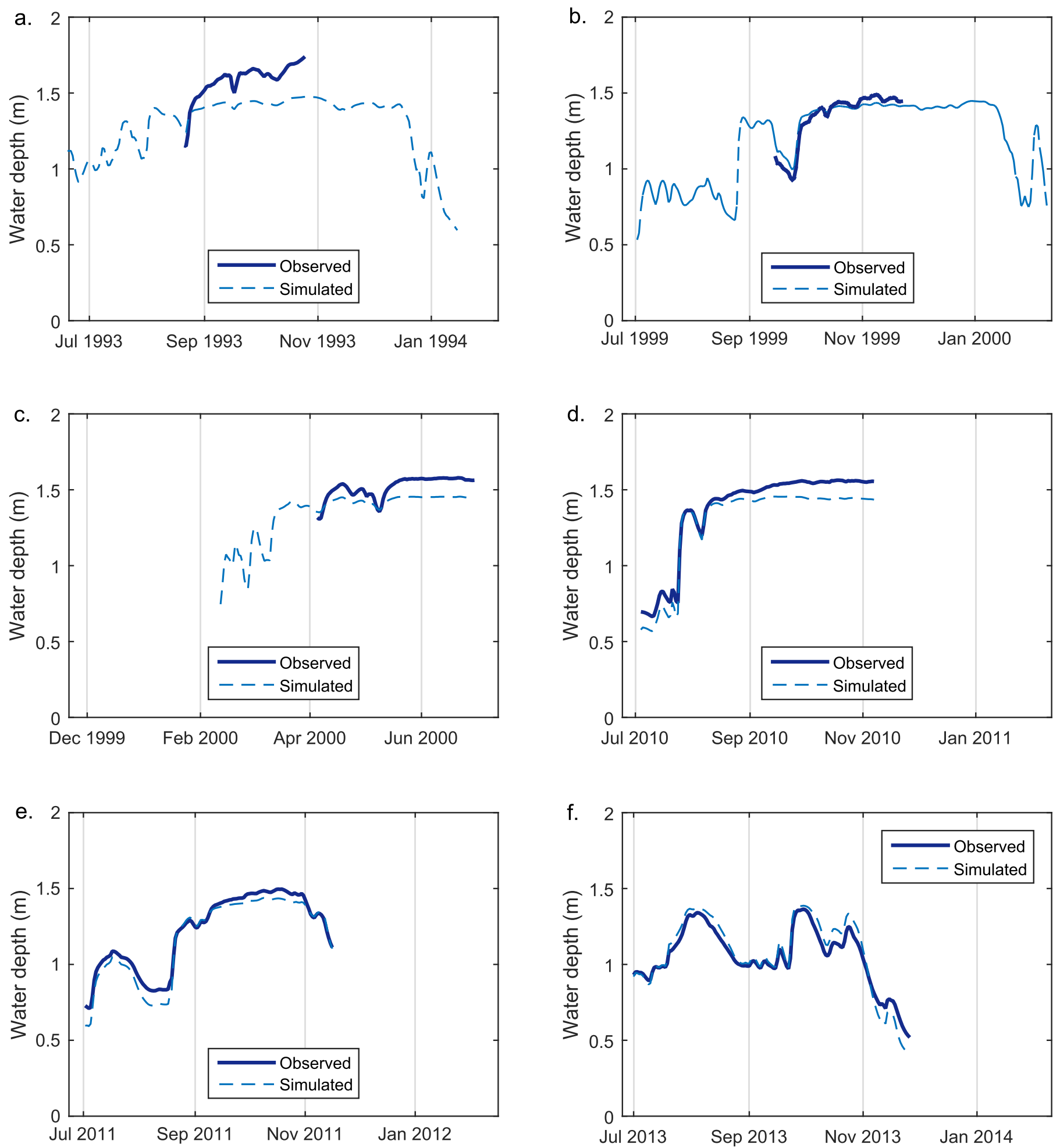

Fig. 3. Comparison of model results with observations at station no. 421151 corresponding to the six different events presented in Table 2.

and temporal coverage availability. Landsat Seasonal Fractional Cover (SFC) data for the six patches of our study site were obtained from AusCover depository (auscover.org.au). The data were developed by the Joint Remote Sensing Research Project (JRSRP, 2014) and used in this publication as an indicator of vegetation health. This dataset is derived from Landsat $5 \mathrm{TM}$, Landsat 7 ETM+ and Landsat 8 OLI images acquired by the United States Geologic Survey (USGS) combined with ground data for Australia. The product provides seasonal estimates of fractions of green vegetation, non-green vegetation (litter, dead leaves and branches) and bare terrain (bare soil, rock, disturbed) in a $30 \mathrm{~m}$ resolution grid. SFC values are calculated from all the satellite data collected during the season (11 to 12 Landsat passes per season minus cloud interference) as the medoid of the data set (Flood, 2013). Of the four seasonal maps available for every year, we selected the autumn map (March to 


\section{Observed}

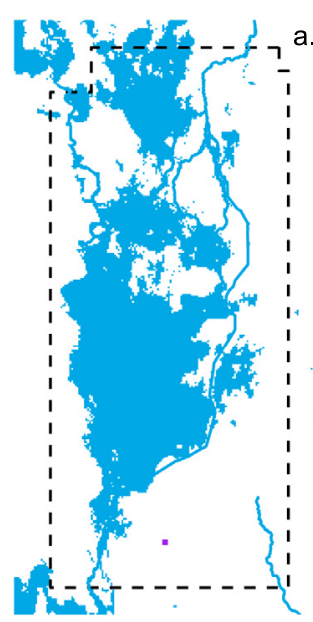

Simulated

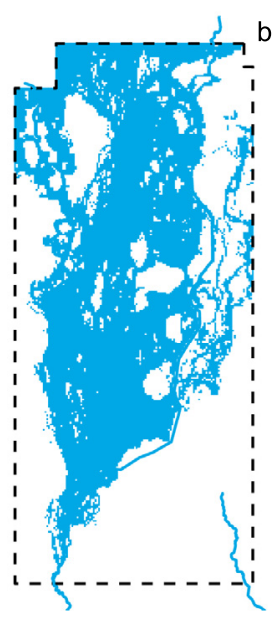

2011
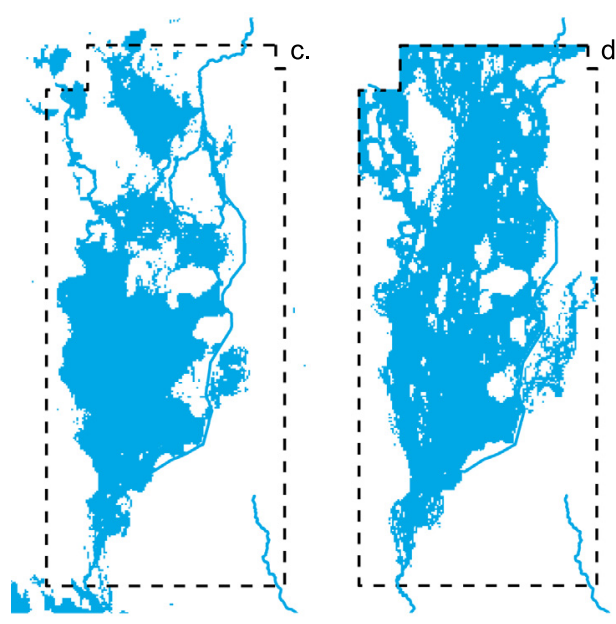

2010
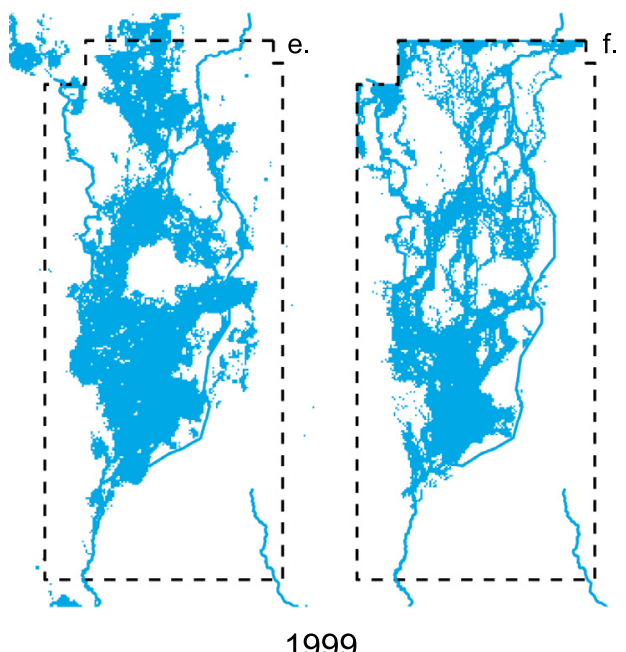

1999

Fig. 4. Comparison of observed and simulated inundation maps in the Northern Marshes for the three calibration events: a) 2011, b) 2010 and c), 1999.
May in the Southern Hemisphere), because the conditions of the vegetation during this period can be related to the inundation regime during the hydrological year (1st June to 30th May) defined in our site by the lowest historical discharges in May. Some species such as Common reed show biomass productivity peaks during this season (Whitaker et al., 2015). Autumn is also the season with less cloud in the region, so the selected datasets were more complete than the other seasonal datasets (see Supplementary Material). Spatially averaged values of SFC were obtained for each of the six patches and used as indicators of vegetation dynamics and health.

\section{Results}

\subsection{Vegetation classification and selection of patches}

As explained in Section 3.3, in order to analyse the relationship between vegetation health and inundation conditions, we re-classified the 16 vegetation types present in the Macquarie Marshes (see Supplementary Material) into smaller number of vegetation associations based on their water requirements following observations reported in the literature (Roberts and Marston, 2011; Rogers, 2011) (Table 4). This procedure resulted in eight associations: Terrestrial species and dryland, Floodplain vegetation, Common reed, Water couch, River red gum, Lignum, Mixed marsh, and Cultivated land. These associations were used to produce vegetation maps for the years 1991, 2008 and 2013 based on data from Wilson (1992), Bowen and Simpson (2009), Bowen and Simpson (2013) (Fig. 6). As the focus of our analysis is on wetland vegetation evolution, both Cultivated land and Lignum vegetation were excluded from the analysis, as this last association was converted to cultivated land by 2008 or presented very little change (Fig. 6). We also excluded Floodplain vegetation as there was no significant change reported within the period of analysis (Bowen and Simpson, 2009, 2013). Mixed marsh is a mix of species dominated by Common reed and Water couch, so we considered that its dynamics could be indirectly assessed based on results for Common reed and Water couch. It must be considered, however, that the resilience of Common reed and Water couch is quite different, so the dynamics of the Mixed marsh will most likely present an intermediate behaviour.

We therefore focussed on the dynamics of three vegetation associations, i.e. Water couch, Common reed and River red gum, for which we identified the range of values of water depth, duration and frequency required for vegetation maintenance (Table 5). Given the focus on transitions from wetland to terrestrial vegetation during droughts, the minimum values of the reported maintenance range were selected as conditions for long-term wetland vegetation survival.

We selected six vegetation patches for analysis, including two Common reed patches (A and B), two Water couch patches (C and D) and two River red gum patches (E and F) (Fig. 7 and Table 6). The patches selected for Common reed and Water couch associations included both transitional (A and C) and non-transitional (B and D) patches. Patches A and $C$ presented a complete succession to terrestrial vegetation by 2008 (Bowen and Simpson, 2010, 2009), and some level of recovery by 2013 (Bowen and Simpson, 2013; Bowen et al., 2017). For River red gum patches, degradation in vegetation condition was analysed instead of transition to other vegetation association because only $1 \%$ of River red gum area fully transitioned (Bowen and Simpson, 2010; Bowen et al., 2017). However, degraded River red gum patches are associated with transitions of the understory from marsh to terrestrial dryland vegetation and high tree mortality. In Patch E, $80 \%$ of trees were reported dead (but still standing) by 2008 and marsh understory was invaded by chenopod shrubland (Bowen and Simpson, 2009). Partial recovery of Patch E was observed in 2013, with percentage of dead trees between $11 \%$ and $40 \%$. On the other hand, Patch $\mathrm{F}$ presented less than $10 \%$ of dead trees and a sustained healthy marsh understory during the whole period of analysis (Bowen and Simpson, 2009, 2013). 


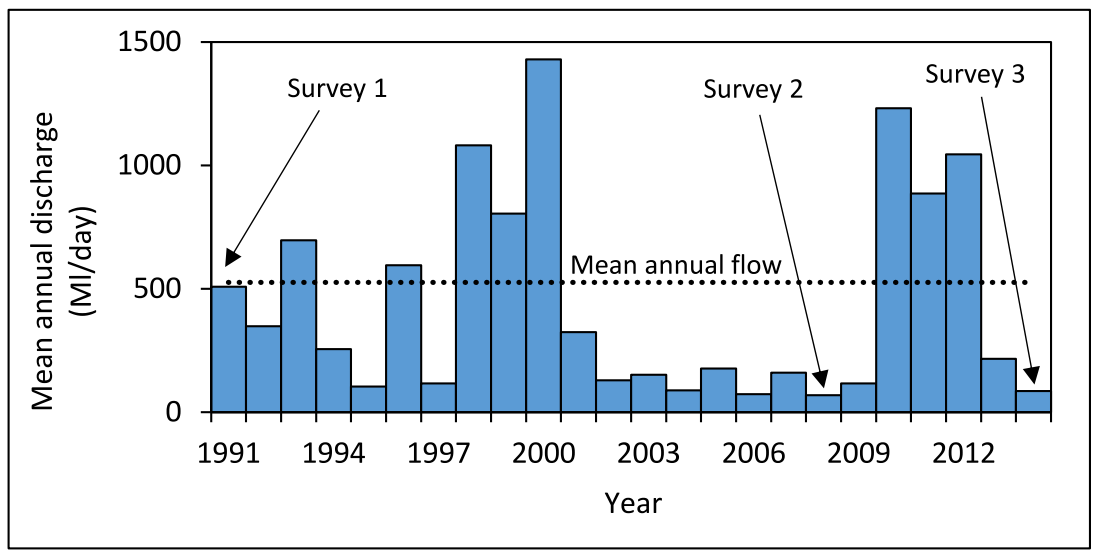

Fig. 5. Mean annual discharges entering the Northern Marshes and timing of vegetation surveys. Discharge values recorded at gauging station no. 421147.

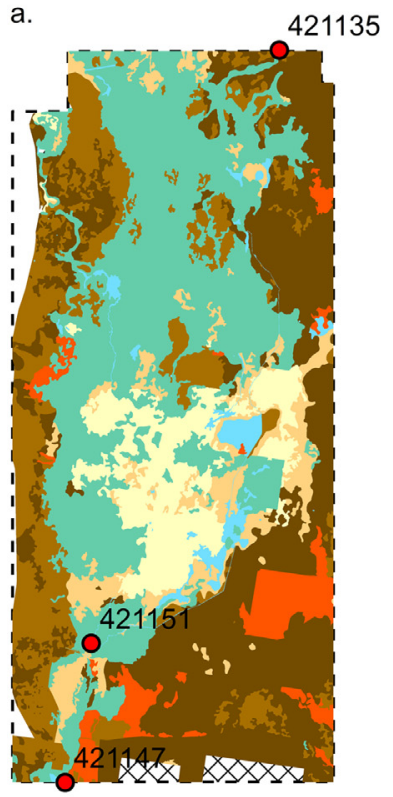

1991

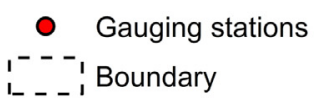

b.

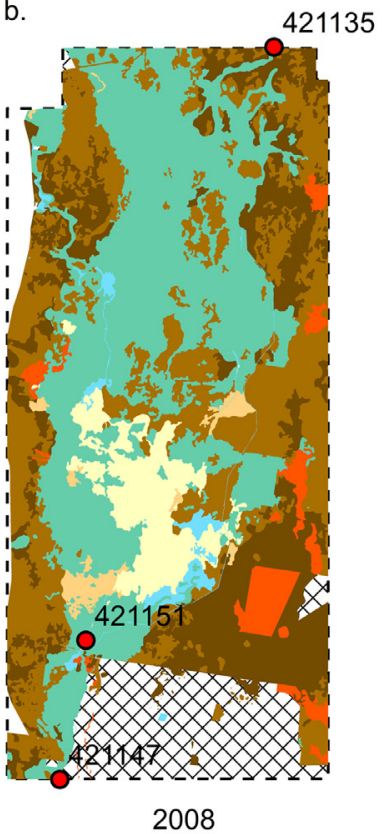

c.

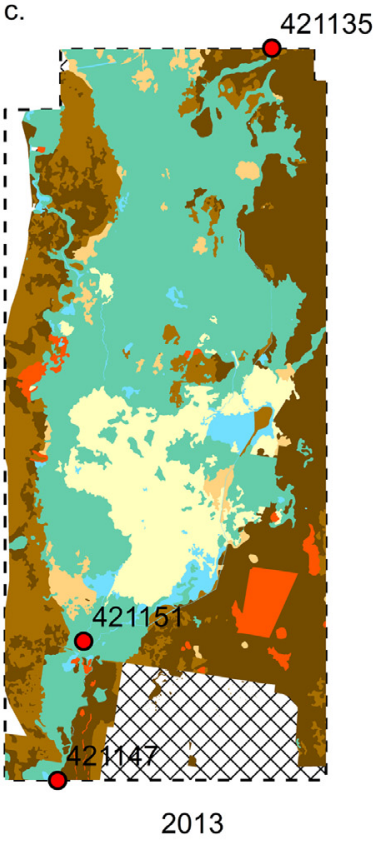

Fig. 6. Maps displaying the vegetation associations based in water requirements for the Northern Marshes in a) 1991, b) 2008 and c) 2013.

\subsection{Inundation regime}

The inundation regime provides the conditions for vegetation establishment/survival and can be described quantitatively in terms of timing, depth, duration, and frequency of inundation (Roberts and Marston, 2011). We do not include in our analysis timing of inundation, i.e. the time of the year flooding occurs because it has remained virtually unchanged over the period of analysis. Managed flows from Burrendong Dam are delivered from September to February coinciding with vegetation requirements (Rogers, 2011). The remaining descriptors of the inundation regime (depth, duration, and frequency) will vary depending on the specific location within the wetland because of the complex topography and flow paths. To calculate the spatially varying characteristics of the inundation regime in the Northern Marshes, we used the 2D hydrodynamic model.

As explained in Section 3.1, using information at the wetland entrance (Pillicawarrina, gauging station No.421147, Fig. 1b) the model was used to simulate the daily time series of inundation depths for the period 1991- 2013, over the entire simulation domain using a $90 \times 90 \mathrm{~m}$ resolution grid (Fig. 1b).

For each hydrological year (June-May), we calculate daily depth and duration of inundation values at every grid point in our computational domain. This information is used to compute depth-duration (percentage time in a year) curves at each point, so that we can identify areas of the patch that have inundation conditions suitable for vegetation maintenance and survival during each hydrological year. Fig. 8 shows how the computed depth-duration curves vary from a wet year (2000) to a dry year (2001) in Common reed. We display the envelope of the depthduration curves corresponding to all grid points within each patch, as each grid point in the patch has a different curve. We also include in the 
Table 4

Vegetation associations of plant communities in the Macquarie Marshes based on water requirements.

\begin{tabular}{|c|c|c|}
\hline Association & Species & Characteristics \\
\hline Terrestrial species and dryland & $\begin{array}{l}\text { Chenopod shrubland (Chenopodiacea) } \\
\text { Grassland } \\
\text { Myall (Acacia pendula) } \\
\text { Wilga (Geijera parviflora) }\end{array}$ & Non-flood dependent species. \\
\hline Floodplain vegetation & $\begin{array}{l}\text { Black box (Eucalyptus largiflorens) } \\
\text { Coolibah (Eucalyptus coolabah) } \\
\text { Poplar box (Eucalyptus pupulnea) } \\
\text { River cooba (Acacia stenophylla) }\end{array}$ & $\begin{array}{l}\text { Less flood-dependent Eucalyptus sp. located in the upper vegetation } \\
\text { gradient. }\end{array}$ \\
\hline River Red Gum association & River Red Gum (Eucalyptus camaldulensis) & $\begin{array}{l}\text { Flood-dependent overstory species. Understory is often present when } \\
\text { frequently inundated. }\end{array}$ \\
\hline Lignum & Lignum (Muehlenbekia fluorenta) & $\begin{array}{l}\text { Grows in riparian zones of channels and stream that are periodically } \\
\text { inundated. }\end{array}$ \\
\hline Common reed & Common reed (Phragmites australis) & $\begin{array}{l}\text { Grows in extensive patches in both stable and fluctuating water } \\
\text { levels and can tolerate some submergence. }\end{array}$ \\
\hline Water couch & Water couch (Paspalum distichum) & $\begin{array}{l}\text { Grows in extensive patches with both stable and fluctuating shallow } \\
\text { water levels. }\end{array}$ \\
\hline Mixed marsh & $\begin{array}{l}\text { Cumbungi (Typha sp.) } \\
\text { Common reed (Phragmites australis) } \\
\text { Water couch (Paspalum distichum) } \\
\text { Sedges }\end{array}$ & $\begin{array}{l}\text { Semipermanent wetland vegetation located in the peripheral areas } \\
\text { of reed beds }\end{array}$ \\
\hline Cultivated & - & - \\
\hline
\end{tabular}

Note: Adapted from Rogers (2011), and Roberts and Marston (2011).Roberts and Marston (2011)

Table 5

Inundation regime requirements for different plant association in the Northern Marshes.

\begin{tabular}{llll}
\hline Plant Association & Duration (\%) & Depth of water $(\mathrm{m})$ & Frequency (years ${ }^{-1}$ ) \\
\hline Common reed & $30 \%$ to $90 \%$ & 0.02 to 0.5 & 0.33 \\
Water couch & $25 \%$ to $67 \%$ & 0.02 to 0.6 & 0.33 \\
River red gum & $25 \%$ to $50 \%$ & 0.02 to 0.6 & $0.14-0.2$ \\
\hline
\end{tabular}

Note: Based on Roberts and Marston (2011).

figures the depth-duration curve that corresponds to the minimum inundation regime suitable for vegetation maintenance/survival (derived from the literature). The figures show that the minimum inundation regime is quite different in the transitional (A) patch compared to the healthy patch (B). The drought-affected patch display envelope bands with considerable portions lying below the minimum inundation curve, particularly during the dry years. The healthy patch, on the other hand, has envelope bands that consistently lie above the minimum inundation curve, indicating that minimum inundation conditions are satisfied or exceeded. It is worth noticing that even during wet years the healthy patches may present areas that do not satisfy the minimum inundation requirements, but these areas are very small (i.e. a small number of grid points within the domain). Similar results were obtained for Water couch and River red gum, which are presented in Supplementary Figs. 1 and 2.

\subsection{Patch analysis}

The Landsat-derived SFC product provides three categories of cover that add up to $100 \%$ : green vegetation, non-green vegetation (litter, dead leaves and branches) and bare terrain (bare soil, rock, disturbed). SFC is supplied in a $30 \times 30 \mathrm{~m}$ grid, so patch values were computed by averaging all the grid values within a patch. For all patches analysed, green and non-green vegetation where the two fractions that showed more sensitivity to changing conditions over the period of analysis, while the bare soil fraction presented low and relatively constant values. We use in our analysis the green SFC as an indicator of vegetation health.

Green SFC (\%) values for all six patches (Fig. 9a-c) show that vegetation coverage changes significantly during the period of analysis, with

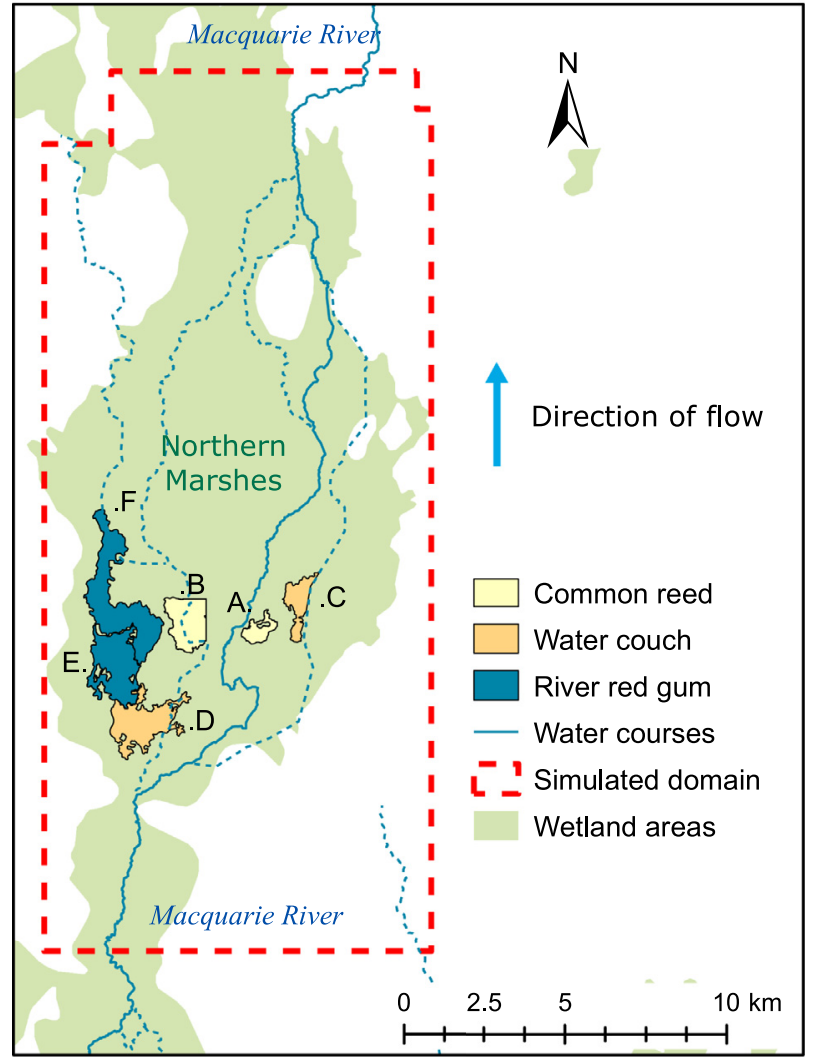

Fig. 7. Selected vegetation patches in the Northern Marshes.

a general trend that responds to the changing hydrological conditions captured by the incoming flows illustrated in Fig. 5. Mean annual discharges during 1989 and 1990 were relatively high, which explains why all patches at the beginning of the analysis period (1991) present a green SFC between $40 \%$ and $50 \%$. Over the period of analysis, green SFC values in the patches that remained healthy during the drought (B, D and F) oscillate around that initial value, while patches A, C and E display a 
Table 6

Characteristics of selected vegetation patches.

\begin{tabular}{|c|c|c|c|c|c|}
\hline Patch & 1991 Vegetation & 2008 Vegetation & 2013 Vegetation & Changes & Conditions \\
\hline A & Common reed & Terrestrial & Common reed & Transitional & - Transition back to wetland understory by 2013 \\
\hline B & Common reed & Common reed & Common reed & Non-transitional & - Good condition in 2008 and 2013 \\
\hline C & Water couch & Terrestrial & Water couch & Transitional & $\begin{array}{l}\text { - Transition back to wetland understory by } 2013 \\
\text { - Intermediate condition in } 2013\end{array}$ \\
\hline D & Water couch & Water couch & Water couch & Non-transitional & - Some chenopod invasion in 2008 and 2013 \\
\hline E & River red gum & $\begin{array}{l}\text { River red gum - poor } \\
\text { condition }\end{array}$ & $\begin{array}{l}\text { River red gum - } \\
\text { intermediate condition }\end{array}$ & Degraded & $\begin{array}{l}\text { - } 80 \% \text { dead trees in } 2008 \\
\text { - } 11 \% \text { to } 40 \% \text { dead trees in } 2013 \\
\text { - Chenopod shrubland invasion in } 2008\end{array}$ \\
\hline $\mathbf{F}$ & River red gum & $\begin{array}{l}\text { River red gum - good } \\
\text { condition }\end{array}$ & $\begin{array}{l}\text { River red gum - good } \\
\text { condition }\end{array}$ & Healthy & $\begin{array}{l}\text { - Less than } 10 \% \text { dead trees } \\
\text { - Healthy mixed marsh understory during the entire period }\end{array}$ \\
\hline
\end{tabular}

Patch A
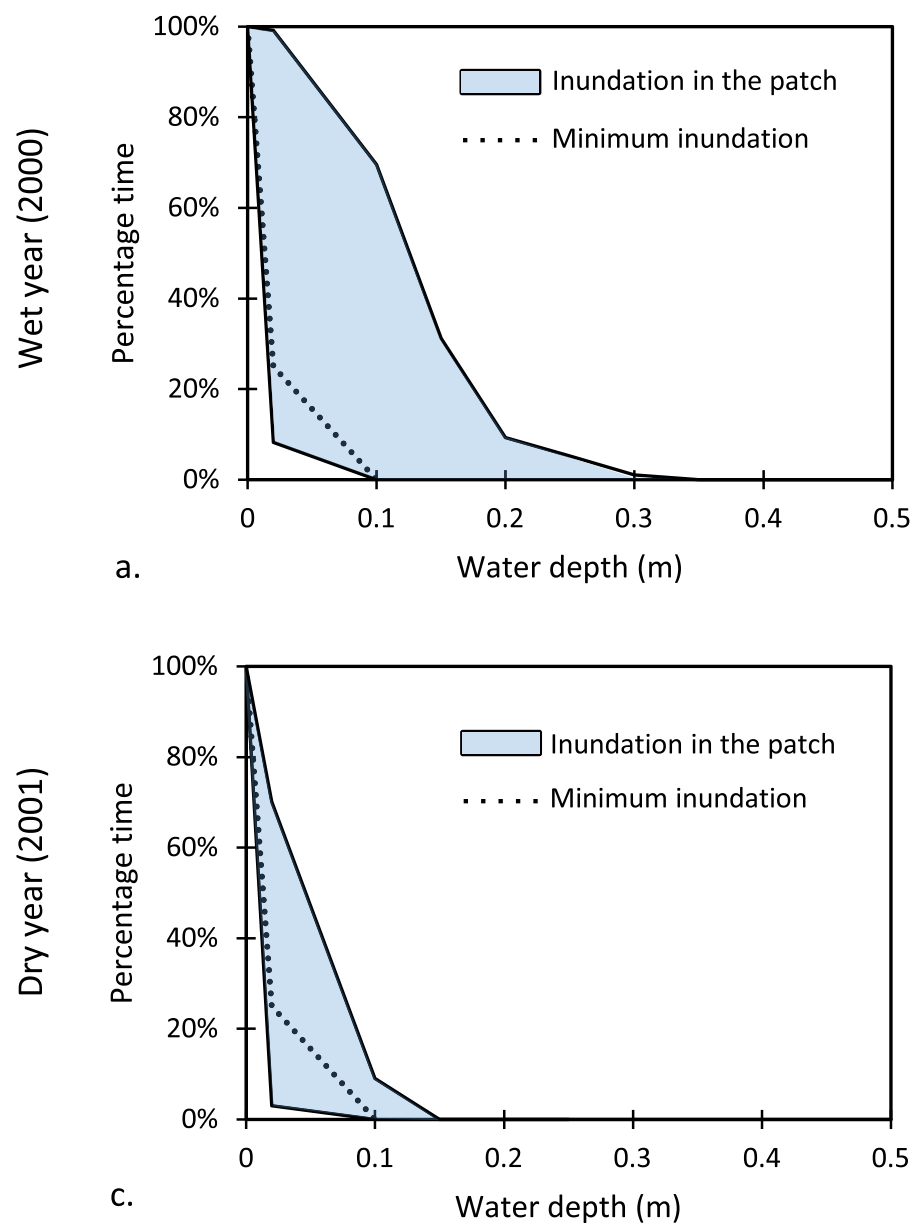

Patch B
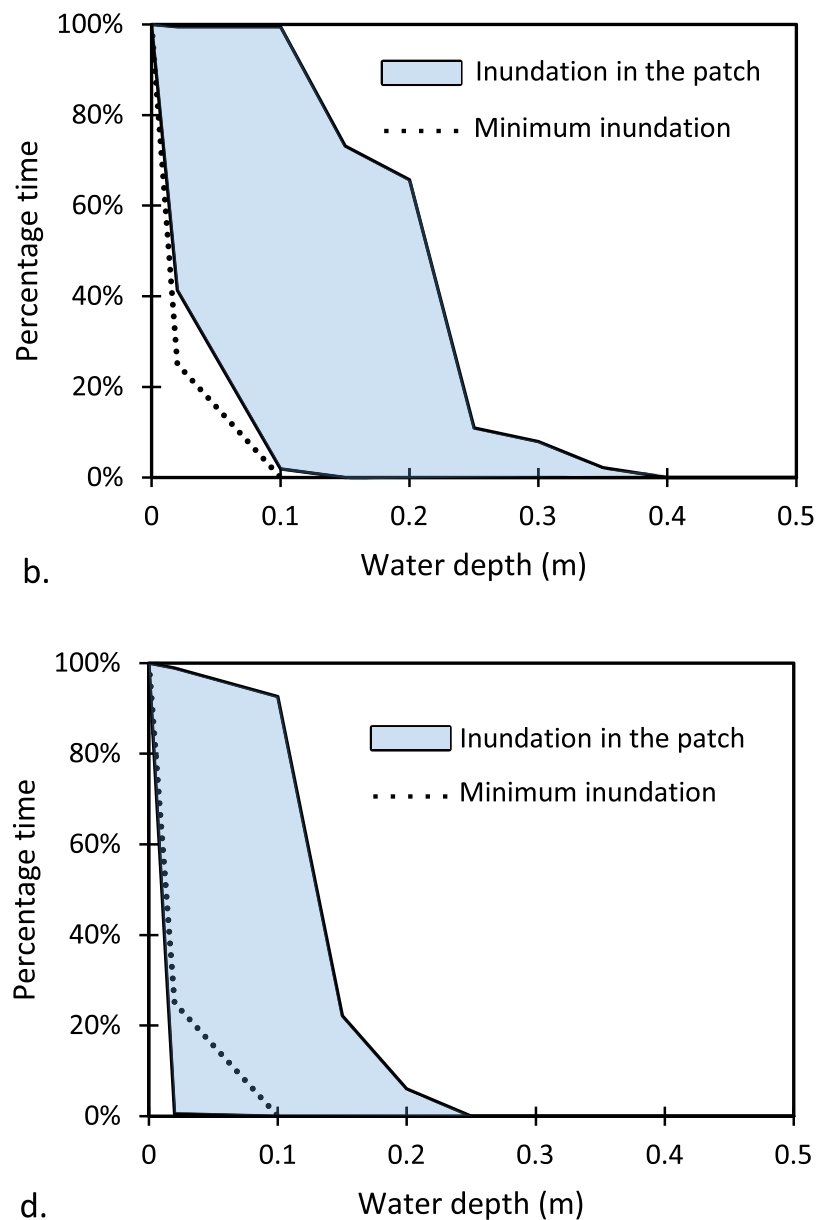

Fig. 8. Simulated inundation conditions in Common reed Patches A and B for a,b) wet year 2000 and c,d) dry year 2001.

clear minimum halfway through the millennium drought (around 2004 to 2005) which can be clearly associated to degradation. We associate this point with the transition from wetland to terrestrial dryland vegetation (Chenopod shrubland invasion). The subsequent increase of green SFC can be interpreted as representing the green fraction of the newly encroached Terrestrial vegetation whose SFC increases in response to increased soil moisture conditions. The transition from Terrestrial vegetation back to marsh vegetation cannot be clearly identified with the information provided in Fig. 9.

The minimum inundation conditions for vegetation maintenance (Table 5) were evaluated in each patch using the depth-duration curves.
Fig. 9d-f display the areal extent of the patches (as percentage area) that satisfy the minimum inundation conditions of Table 5 over the period of analysis (minimum inundation index). Other values within the range presented in Table 5 were also tested to assess the validity of our approach (Supplementary Fig. 3), but only the minimum values of the range provided a clear distinction between healthy and drought-affected patches.

The minimum inundation index is noticeably reduced during the millennium drought in all patches, reaching values close to zero (less than $10 \%$ ) in the transitional and degraded patches (A, C and E). During this period, patches that remained in reasonably healthy conditions (B, D 


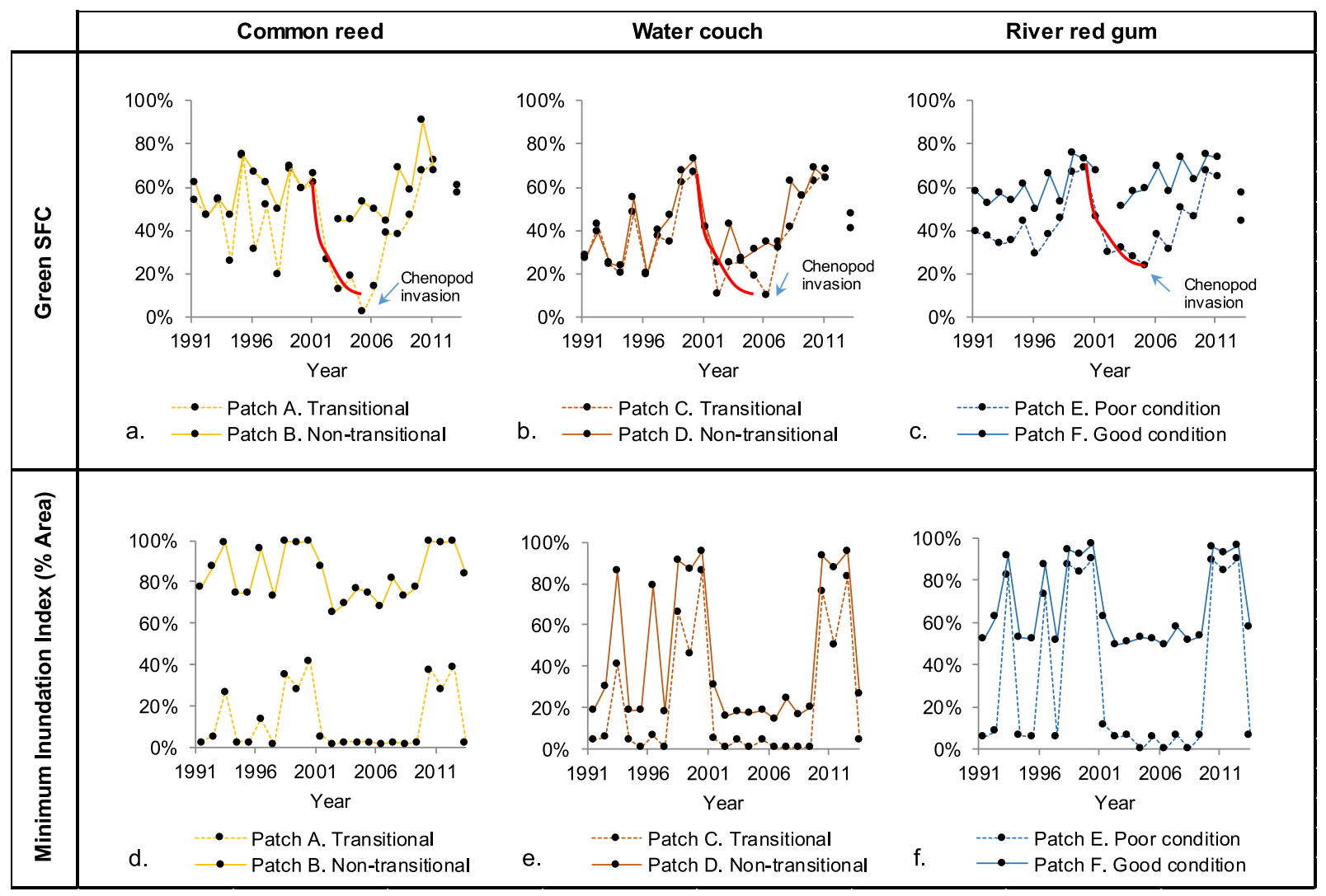

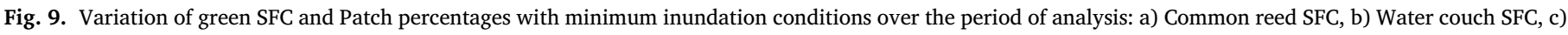

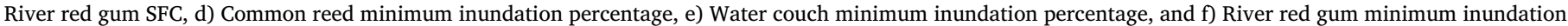

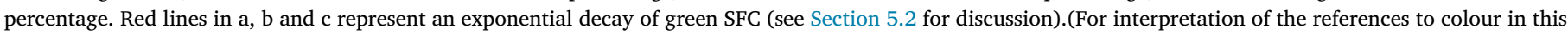
figure legend, the reader is referred to the web version of this article.)

and $\mathrm{F}$ ), consistently had larger values of the minimum inundation index that the drought-affected patches A, C and E. The difference in percentage area with minimum inundation between the healthy and degraded patches during the drought period is about $70 \%$ in Common reeds, $20 \%$ in Water couch and 50\% in River red gum. These differences are consistent with the green SFC results that show differences between healthy and drought-affected patches of $40 \%, 20 \%$ and $30 \%$ for Common reeds, Water couch and River red gum, respectively, during the drought.

The relation between the vegetation condition in the patches (green $\mathrm{SFC} \%$, Fig. 9a-c) and the minimum inundation index (percentage patch area with minimum inundation conditions, Fig. 9d-f) were used to identify patch level (minimum) inundation thresholds for each vegetation association. The relationship between vegetation condition and minimum inundation index is presented in Fig. 10, which excludes SFC values corresponding to years in which Terrestrial vegetation invasion on wetland areas was identified (2005 to 2009).

During the drought (points highlighted in red) patches A, C and E recorded values of minimum inundation index of less than $10 \%$ and levels of green SFC of less than $30 \%$ (Fig. 10). Similar values of low minimum inundation index were also present during dry years outside of the drought period but did not result in transitions or important health degradation (green SFC remained above 30\%) because the dry conditions did not persist over several years (Fig. 9).

Within the drought period, all transitional/degraded patches experienced terrestrial invasion and degradation after four consecutive years of only $10 \%$ of the patch satisfying minimum inundation conditions (Fig. 9). Regarding the healthy patches, Common reed and River red gum maintained minimum inundation conditions over more than 50 to $60 \%$ of its extent, while Water couch was able to remain healthy with only $20 \%$ of its area at minimum inundation conditions.
Fig. 10 also shows that for wet years (minimum inundation index greater than $10 \%$ ) values of green SFC varied between 20 and $80 \%$, without a clear dependence on the inundation conditions.

It must be noted that the threshold of $10 \%$ is a general value that can describe the transition in the selected patches and should be taken as a conservative estimate. Depending on local conditions on other patches, a higher threshold may lead to a transition to terrestrial species or to high River red gum mortality. However, that higher value will always be lower than the minimum inundation index of the healthy patches of the same vegetation (Fig. 9).

\subsection{Inter-annual frequency of minimum inundation conditions}

Selection of inundation thresholds for potential transition must consider the frequency of inundation and the fact that dryland wetland vegetation is resilient to dry conditions (Capon and Reid, 2016). Fig. 9 shows that patches $\mathrm{A}, \mathrm{C}$ and $\mathrm{E}$ were subject to minimum inundation conditions in less than $10 \%$ of its area for four consecutive years (2001 to 2004) before transitioning to terrestrial vegetation in 2005, resulting in a frequency of one in four years. These results agree with values proposed by (Roberts and Marston, 2011), of one in three years of minimum inundation frequency needed for Common reed and Water couch survival. Roberts and Marston (2011) also reported a minimum frequency of one in three years for River red gum forest and one in five years for River red gum woodlands, so our estimates of one in four years is consistent as our patches have both forest and woodland. In addition, signs of degradation of the drought affected patch (Patch E) included $80 \%$ dead trees as well as understory transition from Mixed marsh to Terrestrial vegetation (Bowen and Simpson, 2009, 2010). Our estimates of a one in four-year frequency with minimum inundation conditions is 


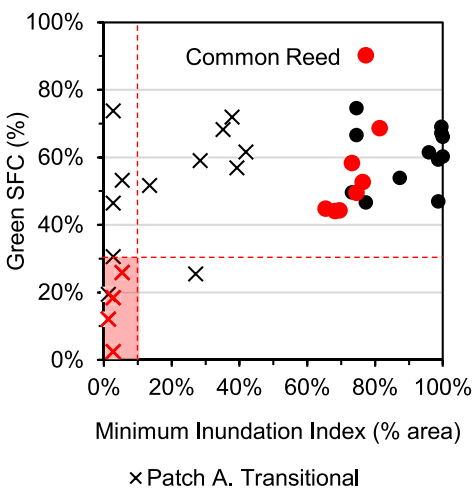

a. $\quad$ Patch B. Non-transitional

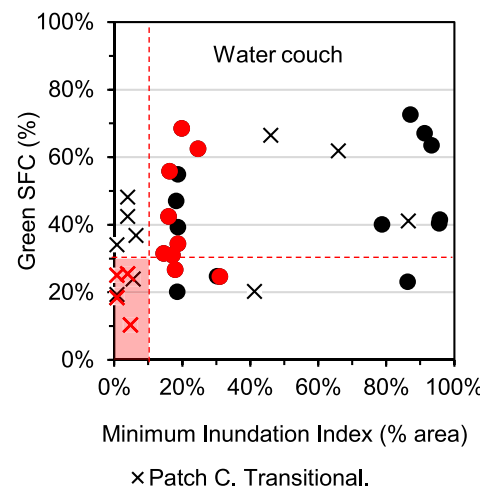

b. $\quad$ Patch D. Non-transitional.

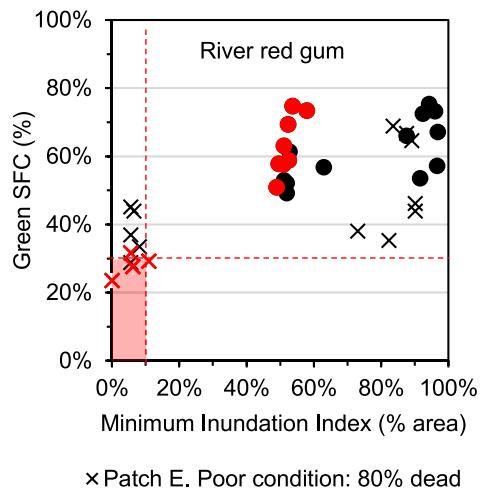

C. Patch F. Good condition: $<10 \%$ dead

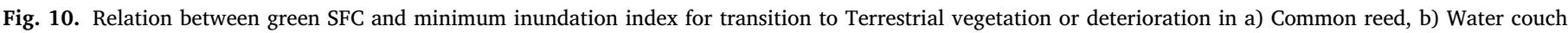

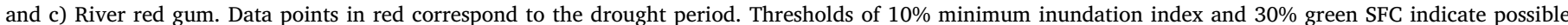
transition to terrestrial vegetation.(For interpretation of the references to colour in this figure legend, the reader is referred to the web version of this article.)

consistent with observations in patch $\mathrm{E}$ and also with the minimum frequency of the understory species Common reeds and Water couch that dominate the mixed marsh understory of River red gum.

\section{Discussion}

\subsection{Vegetation-water dynamics within healthy and degraded patches}

As described in the introduction, the soil water used by vegetation in dryland floodplain wetlands almost exclusively depends on overbank floods produced by runoff originated in the upstream catchments (Wen et al., 2012). Releases from Burrendong Dam periodically flood the wetland and the spatial distribution of the overbank inundation determines the diverse vegetation composition.

The incorporation of spatially distributed hydrodynamic simulations into our analysis framework allowed us to estimate the appropriate inundation regime drivers that have been identified in the literature as key for the survival of dryland wetland vegetation during droughts. These drivers include depth and duration of inundation during the 12 months (i.e. hydrodynamic model results from June to May) preceding the vegetation status assessment (i.e. green SFC data from March to May) and the inter-annual frequency of inundation. Once hydrodynamic and vegetation processes are linked at the corresponding temporal scales, we can investigate the interactions to determine simple cause-effect relations between inundation regime and vegetation response. The changes in vegetation that we identified during the period of analysis included variations in the average green SFC of patches and transitions from wetland to terrestrial vegetation. Patches of different vegetation associations showed a distinctive response to the inundation regime but there were also some trends common to all vegetation associations considered.

Common reed is known to be highly persistent as it can survive under a wide range of inundation regimes, including almost permanently inundated conditions (Rogers, 2011; Roberts and Marston, 2011). The results from Common reed patches show a clear distinction between transitional Patch A and non-transitional Patch B. Patch B satisfied minimum inundation conditions in more than $70 \%$ of the patch during the entire period of analysis (Fig. 9d) and displayed green SFC values of $60 \%$ on average (Fig. 9a). Patch A, located in less favourable wetland area, was under minimum inundation conditions in a smaller proportion of the patch area (always below 40\%); however, the values of green SFC can reach the same levels of Patch A with moderate values of area with minimum inundation (20 to 40\%) (Fig. 9a and b). This finding suggests that the magnitude of the inundation (as quantified by the $\%$ area with minimum inundation) is not the main driver of vegetation response in this patch, as long as the minimum inundation conditions are satisfied over more than $20 \%$ of the patch area. This result is in agreement with observations by Leigh et al. (2010) indicating that the sequence and frequency of flow pulses rather than the magnitude drives the vegetation dynamics of dryland wetland vegetation.

Similarly to Common reed, Water couch survives under a diverse range of inundation regime conditions (Blanch et al., 1999), including almost completely permanent inundation without noticeable effects on vegetation growth (Hsiao and Huang, 1989). Both patches of Water couch $\mathrm{C}$ and $\mathrm{D}$ experienced periods with quite limited inundation, particularly during the drought, which is consistent with the low green SFC values observed in these patches (Fig. 9b). Under limited inundation conditions, Water couch undergoes stress as their root system is not able to access water deeper in the soil (Rogers, 2011). Environmental water releases during the drought $(2005 / 2006)$ provided enough inundation in Patch D to sustain healthy conditions (Driver and Knight, 2007); however, Patch $C$ received less water as it was located further away from the main water course. The poor inundation conditions during the drought in Patch C resulted in reductions in green SFC and transition to Terrestrial vegetation in 2005. The lack of sufficient inundation would have most certainly depleted the seedbank, as Water couch seeds can only survive for up to two years of drought (Roberts and Marston, 2011). Nevertheless, patch C did transition back to Water couch by 2013 (Bowen et al., 2017), probably as a result of regrowth from rootstocks that can persist for up to seven dry years (Roberts and Marston, 2011). This recovery, however, was not complete. Recovery from rootstocks is slower than from seeds and more likely to fail as regeneration depends on the presence of mature, healthy plants with trailing stems (DECCW, 2010). Compared to Common reed, Water couch does not display the same resilience characteristics, which may have contributed to Water couch losses in other areas of the Macquarie Marshes (Bowen et al., 2017). In those areas, encroachment of degraded Water couch by other wetland vegetation associations was reported after the drought. Transitions between different wetland associations after a drought have also been observed in the Barmah Forest (Colloff et al., 2014), where River red gum encroached Spiny mud grass due to changes in the inundation regime that followed the end of Millennium drought. In our site, Water couch patches were not physically close to any other wetland association with the capability to encroach after the drought, which may explain why they were able to survive.

River red gum inundation requirements vary widely depending on whether they are in the riparian zone or not and whether they access groundwater (Wen et al., 2009; Wen et al., 2010; Doody et al., 2015; Catelotti et al., 2015; Roberts and Marston, 2011; Mensforth et al., 1994). In the Macquarie Marshes, there is evidence that River red gum trees obtain most water from the unsaturated upper soil layer and less 
from groundwater due to high salinity (Hollins et al., 2009); therefore, flooding is the main driver of River red gum dynamics in our study. The degraded Patch E experienced little to no flow during the drought, while Patch $\mathrm{F}$ had substantial areal extent satisfying minimum inundation requirements (above 50\%) (Fig. 9). The inundation regime for Patch $\mathrm{F}$ was enough to maintain good conditions with minimum tree mortality and healthy Mixed marsh understory throughout the drought. On the other hand, in Patch E the limited inundation during the drought stressed the vegetation and promoted the colonization of the understory by Terrestrial vegetation (Table 6). Increase of inflows after the drought produced high inundation levels and the retreat of terrestrial vegetation (Bowen and Simpson, 2013; Bowen et al., 2017). Recovery of River red gum was probably due to epidermic growth of degraded trees triggered by inundations after the break of the drought and establishment of new seedlings and saplings.

\subsection{Vegetation dynamics during droughts}

Between inundations, the vegetation uses different persistence mechanisms. Tree species like River red gum have adapted to dry periods between inundations by implementing hydraulic redistribution of water in the soil profile via their root system: a shallow dense root network with deeper taproots. After rainfall or inundations, the shallow root network can access the water in the soil while the taproots can move water from the upper soil layers to deeper soil layers and implement the inverse mechanism when water is required (Eamus et al., 2006). Use of deeper water in the soil, however, can be limited in cases of high soil salinity like in the Macquarie Marshes (Hollins et al., 2009). The root network of the understory vegetation (Common reed, Water couch and Mixed marsh) is shallower than the tree species and they do not use hydraulic redistribution of water in the soil profile. In the region, understory vegetation is expected to experience some degree of deterioration between inundations, but can recover completely from rhizomes, shoots and seedbanks (Capon and Reid, 2016).

Even though each vegetation association display distinct characteristics, there are some common patterns. During wet years (more than $10 \%$ area with minimum inundation), all vegetation patches show level of green SFC that did not directly correlate with the \% area with minimum inundation (Fig. 10). Wet years are associated with levels of green SFC that vary widely (mostly between $30 \%$ and $80 \%$ ) but never reach values below $20 \%$. Transitional/degraded patches A, C and E that receive inconsistent inundation present more variability in green SFC but during wet years the green SFC values are similar to those of the unaffected patches. This behaviour is consistent with the high resilience of dryland vegetation, which can recover fully from poor conditions after just one wet year. The fact that we did not find any clear correlation between the percentage area with minimum conditions and the corresponding green SFC value is in agreement with results from (Leigh et al., 2010) indicating that the sequence and frequency of flow pulses rather than the magnitude drives the vegetation dynamics of dryland wetland vegetation.

During a drought, vegetation does not immediately disappear. When the percentage of patch area with minimum inundation conditions drops below $10 \%$, the reduction of green SFC is gradual. As we show in Fig. 9ac using a red line, the reduction can be roughly characterised by an exponential decay of green SFC with a decay constant $k$ specific of each vegetation association. Green SFC of Common reed and Water couch decay at a faster rate (with a decay constant $k=0.6 \mathrm{y}^{-1}$ ) than River red gum (with $k=0.2 \mathrm{y}^{-1}$ ) (Fig. 9). Exponential decay functions have been used to characterise reductions in soil moisture in drylands during interstorm periods (Franz et al., 2012) so our findings are consistent with a drying patch in which soil water available for plant use is exponentially decreasing over time. The fact that the River red gum patch has the lowest decay rate indicates a better capability to access water in the soil and withstand drought conditions than the other wetland vegetation, in agreement with Roberts and Marston (2011) and Rogers (2011).
This exponential decay can be associated with the observed minimum inundation frequency required for vegetation maintenance and the Terrestrial vegetation invasion observed in the transitional/degraded patches A, C and E. The decay reduces the initial green SFC values in 2001 to the lowest values observed in 2005 (less than 20\%), at which point wetland vegetation, particularly Common reed and Water couch, can no longer survive as it has experienced the minimum inundation frequency (one in four years). River red gum may survive even under such stressing conditions, but its understory (mainly composed of Common reed and Water couch) is less resilient and disappears. Terrestrial dryland vegetation (Chenopod shrubland) is then able to colonise these areas.

The above discussion does not imply that wetland vegetation will deteriorate only after the minimum inundation index reaches the threshold value of $10 \%$. Significant reductions in SFC will occur at higher values of the minimum inundation index. However, conditions after reaching the threshold level are so extreme that vegetation cannot be maintained or partially regenerate and is prone to terrestrial vegetation invasion.

\section{Summary and conclusion}

This study focuses on understanding the response of vegetation to hydrologic variability in an arid wetland in Australia over a period of 22 years, which includes the severe effects of the Millennium drought. As widely recognized in the literature, the dominant drivers of vegetation health/maintenance in arid wetlands include the annual depth-duration inundation regime and the inter-annual frequency of inundation. However, long-term detailed records of inundation are rarely availably in this type of environment, so here we use simulations from a calibrated hydrodynamic model to compute spatially distributed depths, duration and frequency of inundation in our study site (the Northern Marshes). Vegetation response is evaluated using vegetation classification maps and remotely sensed data (Landsat derived green Seasonal Fractional Cover at the end of the growing season) as an indicator of vegetation status.

Vegetation status is assessed on selected patches representative of key wetland vegetation associations (Common reed, Water couch and River red gum). We define minimum inundation conditions for vegetation survival in terms of depth and annual duration of inundation, based on values reported in the literature. For each vegetation association we identify (through existing vegetation maps) patches that experienced degradation and reference patches that remained healthy throughout the 20-year period. For those patches we assess the adequacy of the inundation regime by developing an index that reflects the percentage patch area that satisfies the minimum inundation conditions (minimum inundation index). The relation between this index and the indicator of vegetation health derived from green Seasonal Fractional Cover (SFC), enables us to identify threshold inundation conditions that can trigger degradation. We combine this information with the inter-annual frequency of these episodes to identify vegetation transitions into degraded states.

We found that patches that undergo serious degradation have distinctively lower areas satisfying the minimum inundation requirement than the reference patches during the Millennium drought period, with the minimum inundation index remaining consistently below $10 \%$. In response to these persistently dry conditions in over $90 \%$ of the patch area, green SFC gradually decreases reflecting vegetation decay. The decay rate is faster for the vegetation associations with shorter roots (Common reed and Water couch) than for the woody vegetation with longer roots (River red gum) probably due to the inability of the short roots to access deeper water in the soil or due to the ability of grasses to quickly senesce above-ground parts as a drought response. After four consecutive years with less than $10 \%$ area with minimum inundation conditions, vegetation green SFC decreases to $20 \%$ or less for all vegetation associations, at which point Terrestrial vegetation invasion occurs (Chenopod shrubland encroachment). 
Our results suggest that for wet years (when minimum inundation remains consistently above $10 \%$ ), the response of vegetation in all patches (degraded and reference) does not seem to be associated with the degree of inundation in the patch during that particular year. The green SFC varies depending on vegetation type, but is not directly correlated to inundation conditions during the previous year (Fig. 10). This result is consistent with observations indicating that sequence and frequency of flow pulses rather than the magnitude drives the vegetation dynamics of dryland wetland vegetation.

These two distinct modes of vegetation response suggest the existence of threshold behaviour. Levels below $10 \%$ of minimum inundation area noticeably degrade vegetation. Vegetation can recover quickly if this threshold is only maintained for one or two years. Values below $10 \%$ of minimum inundation area for more extended drought periods result in a gradual decrease of vegetation to almost complete disappearance after four years. Vegetation invasion occurs only after wetland vegetation green SFC values have considerably reduced after four years below $10 \%$ of minimum inundation area. The threshold value of green SFC of wetland vegetation for Terrestrial vegetation invasion is $20 \%$ green SFC.

Our main findings are thus:

- The minimum inundation index, which links inundation with vegetation requirements, can be used to identify different vegetation behaviour during wet and dry conditions and predict wetland vulnerability to terrestrial vegetation invasion.

- During wet periods (minimum inundation index above 10\%), green SFC values in both healthy and drought-affected patches are not directly correlated to the minimum inundation index.

- During the drought, drought affected patches display a minimum inundation index below $10 \%$ and green SFC below $30 \%$.

- During the drought, green SFC decays exponentially in drought affected patches, and after four years of minimum inundation below $10 \%$ green SFC reduces to less than $20 \%$, at which point terrestrial vegetation invasion occurs.

The two thresholds identified in our analysis can be used to support adaptive management, by clearly identifying patches that are at risk of degradation and terrestrial vegetation invasion ( $20 \%$ green SFC) and prioritise watering to recovery levels (above 10\% minimum inundation index). Our analysis can also be used to develop predictive tools to assess future vegetation response to changing climatic, hydrological or management conditions.

\section{Acknowledgments}

S.S. was supported by a University of Newcastle PhD scholarship with partial support from the NSW Office of Environment and Heritage. J.R. acknowledges support from the NSW Office of Environment and Heritage. P.S., G.W. and S.S. acknowledge support from the Australian Research Council (grant DP140104178 and Future Fellowship grant FT140100610 for P.S.).

\section{Supplementary materials}

Supplementary material associated with this article can be found, in the online version, at doi:10.1016/j.advwatres.2019.04.016.

\section{References}

Andela, N., Liu, Y.Y., Van DIJK, A.I.J.M., De Jeu, R.A.M., Mcvicar, T.R., 2013. Global changes in dryland vegetation dynamics (1988-2008) assessed by satellite remote sensing: comparing a new passive microwave vegetation density record with reflective greenness data. Biogeosciences 10, 6657-6676.

Arcement, G.J., Schneider, V.R., 1989. Guide for selecting Manning's roughness coefficients for natural channels and flood plains. Water Supply Paper. US Government Printing Office.

Basile, P.A., Riccardi, G.A., Zimmermann, E.D., Stenta, H.R., 2010. Simulation of erosion-deposition processes at basin scale by a physically-based mathematical model. Int. J. Sediment Res. 25, 91-109.
Berney, P., Hosking, T., 2016. Opportunities and challenges for water-dependent protected area management arising from water management reform in the MurrayDarling Basin: a case study from the Macquarie Marshes in Australia. Aqua. Conserv. Marine Freshwater Ecosyst. 26, 12-28.

Bino, G., Sisson, S.A., Kingsford, R.T., Thomas, R.F., Bowen, S., 2015. Developing state and transition models of floodplain vegetation dynamics as a tool for conservation decision-making: a case study of the Macquarie Marshes Ramsar wetland. J. Appl. Ecol. 52, 654-664.

Bishop-Taylor, R., Tulbure, M.G., Broich, M., 2017. Surface-water dynamics and land use influence landscape connectivity across a major dryland region. Ecol. Appl. 27, 1124-1137.

Blanch, S.J., Ganf, G.G., Walker, K.F., 1999. Tolerance of riverine plants to flooding and exposure indicated by water regime. Regulat. Rivers Res. Manag. 15, 43-62.

Bowen, S., Simpson, S., 2009. Vegetation Map of the Macquarie Marshes. NSW Department of Environment, Climate change and Water, Sydney.

Bowen, S. \& Simpson, S. 2010. Changes in extent and condition of the vegetation communities of the Macquarie Marshes Floodplain 1991-2008: fFinal report to the NSW Wetland Recovery Program. Sydney: River and Wetlands Unit, Department of Environment, Climate Change and Water, NSW.

Bowen, S., Simpson, S., 2013. Vegetation Map of the Macquarie Marshes. NSW Office of Environment and Heritage, Sydney.

Bowen, S., Simpson, S.L., Hosking, T., Shelly, D.S., 2017. Changes in Extent and Condition of the Vegetation of the Macquarie Marshes and Floodplain 1991-2008-2013. NSW Office of Environment and Heritage, Sydney.

Brock, M., Casanova, M., 1997. Plant Life at the Edge of Wetlands: Ecological Responses to Wetting and Drying Patterns. Elsevier Science Ltd., Oxford.

Capon, S.J., 2003. Plant community responses to wetting and drying in a large arid floodplain. River Res. Appl. 19, 509-520.

Capon, S.J., Reid, M.A., 2016. Vegetation resilience to mega-drought along a typical floodplain gradient of the southern Murray-Darling Basin, Australia. J. Veget. Sci. 27, 926-937.

Catelotti, K., Kingsford, R.T., Bino, G., Bacon, P., 2015. Inundation requirements for persistence and recovery of river red gums (Eucalyptus camaldulensis) in semi-arid Australia. Biol. Conserv. 184, 346-356.

Chen, Y., Huang, C., Ticehurst, C., Merrin, L., Thew, P., 2013. An evaluation of MODIS daily and 8-day composite products for floodplain and wetland inundation mapping. Wetlands 33, 823-835.

Colloff, M.J., Ward, K.A., Roberts, J., 2014. Ecology and conservation of grassy wetlands dominated by spiny mud grass Pseudoraphis spinescens in the southern Murray-Darling Basin, Australia. Aqua. Conserv. Marine Freshwater Ecosyst. 24, 238-255.

Congalton, R.G., 1991. A review of assessing the accuracy of classifications of remotely sensed data. Remote Sens. Environ. 37, 35-46.

Cui, X., Gibbes, C., Southworth, J., Waylen, P., 2013. Using remote sensing to quantify vegetation change and ecological resilience in a semi-arid system. Land 2, 108.

Cunge, J.A., 1975. Two dimenssional modeling of floodplains. In: Mahmood, K., Yevjevich, V. (Eds.), Unsteady Flow in Open Channels. Water Resources Publications, Colorado.

DECCW, 2010. Macquarie Marshes Adaptive Environmental Management Plan: Synthesis of information projects and actions, NSW Wetland Recovery Program. Department of Environment, Climate Change and Water NSW.

Doody, T.M., Colloff, M.J., Davies, M., Koul, V., Benyon, R.G., Nagler, P.L., 2015. Quantifying water requirements of riparian river red gum (Eucalyptus camaldulensis) in the Murray-Darling Basin, Australia - implications for the management of environmental flows. Ecohydrology 8, 1471-1487.

Driver, P., Knight, C., 2007. Macquarie Marshes 2005/06 Environmental Flow. Responses of Groundcover Plants to Environmental Flow. Report to the Macquarie Marshes Environmental Flow Reference Group.

Eamus, D., Hatton, T., Cook, P., Colvin, C., 2006. Ecohydrology: Vegetation function, Water and Resource Management. Csiro Publishing.

Fensham, R.J., Fairfax, R.J., Pocknee, D., Kelley, J., 2004. Vegetation patterns in permanent spring wetlands in arid Australia. Aust. J. Bot. 52, 719-728.

Flood, N., 2013. Seasonal composite landsat TM/ETM+ images using the medoid (a multi-dimensional median). Remote Sensing 5, 6481.

Foti, R., Del Jesus, M., Rinaldo, A., Rodriguez-Iturbe, I., 2012. Hydroperiod regime controls the organization of plant species in wetlands. Proc. Natl. Acad. Sci. 109, 19596-19600.

Franz, T.E., Caylor, K.K., King, E.G., Nordbotten, J.M., Celia, M.A., Rodríguez-Iturbe, I., 2012. An ecohydrological approach to predicting hillslope-scale vegetation patterns in dryland ecosystems. Water Resour. Res. 48.

Garcia, M.L., Basile, P.A., Riccardi, G.A., Rodriguez, J.F., 2015. Modelling extraordinary floods and sedimentological processes in a large channel-floodplain system of the Lower Paraná River (Argentina). Int. J. Sediment Res. 30, 150-159.

Green, J.C., 2005. Modelling flow resistance in vegetated streams: review and development of new theory. Hydrol. Processes 19, 1245-1259.

Guerschman, J.P., Hill, M.J., Renzullo, L.J., Barrett, D.J., Marks, A.S., Botha, E.J., 2009. Estimating fractional cover of photosynthetic vegetation, non-photosynthetic vegetation and bare soil in the Australian tropical savanna region upscaling the EO-1 Hyperion and MODIS sensors. Remote Sens. Environ. 113, 928-945.

Guerschman, J.P., Scarth, P.F., Mcvicar, T.R., Renzullo, L.J., Malthus, T.J., Stewart, J.B., Rickards, J.E., Trevithick, R., 2015. Assessing the effects of site heterogeneity and soil properties when unmixing photosynthetic vegetation, non-photosynthetic vegetation and bare soil fractions from Landsat and MODIS data. Remote Sens. Environ. 161, 12-26.

Heimhuber, V., Tulbure, M.G., Broich, M., 2017. Modeling multidecadal surface water inundation dynamics and key drivers on large river basin scale using multiple time series of Earth-observation and river flow data. Water Resour. Res. 53, 1251-1269. 
Hollins, S., Meredith, K., Twining, J., 2009. Study of Groundwater-Surface Water Interactions in the Macquarie Marshes and Sources of Water for Riparian Vegetation Transpiration. NSW Department of Environment and Climate Change.

Hsiao, A.I. \& Huang, W.Z. 1989. Effects of flooding on rooting and sprouting of isolated stem segments and on plant growth of Paspalum distichum L. Effets de l'immersion sur l'enracinement et la pousse de segments de tiges isolées et sur la croissance des plantes de Paspalum distichum L., 29, 335-344.

JRSRP, 2014. Seasonal Fractional Cover - Landsat, JRSRP Algorithm, NSW Coverage, Joint Remote Sensing Research Project. NSW Office of Environment and Heritage.

Karnieli, A., Bayarjargal, Y., Bayasgalan, M., Mandakh, B., Dugarjav, C., Burgheimer, J., Khudulmur, S., Bazha, S.N., Gunin, P.D., 2013. Do vegetation indices provide a reliable indication of vegetation degradation? A case study in the Mongolian pastures. Int. J. Remote Sens. 34, 6243-6262.

Keesstra, S., Nunes, J.P., Saco, P., Parsons, T., Poeppl, R., Masselink, R., Cerdà, A., 2018. The way forward: can connectivity be useful to design better measuring and modelling schemes for water and sediment dynamics. Sci. Total Environ. 644, 1557-1572.

Kingsford, R.T., 2000. Ecological impacts of dams, water diversions and river management on floodplain wetlands in Australia. Austral. Ecol. 25, 109-127.

Larkin, Z.T., Ralph, T.J., Tooth, S., McCarthy, T.S., 2017. The interplay between extrinsic and intrinsic controls in determining floodplain wetland characteristics in the South African drylands. Earth Surf. Processes Landforms 42, 1092-1109.

Lawley, V., Lewis, M., Clarke, K., Ostendorf, B., 2016. Site-based and remote sensing methods for monitoring indicators of vegetation condition: an Australian review. Ecol. Indic. $60,1273-1283$.

Leigh, C., Sheldon, F., Kingsford, R.T., Arthington, A.H., 2010. Sequential floods drive booms and wetland persistence in dryland rivers: a synthesis. Mar. Freshwater Res. 61, 896-908.

Masman, K., Johnstone, M., 2000. Reedbed Country: the Story of the Macquarie Marshes. Macquarie Marshes Management Committee, Tamworth, New South Wales, Australia.

Mensforth, L.J., Thorburn, P.J., Tyerman, S.D., Walker, G., R., 1994. Sources of water used by riparian eucalyptus camaldulensis overlying highly saline groundwater. Oecologia 100, 21-28.

Moriasi, D.N., Arnold, J.G., Van Liew, M.W., Bingner, R.L., Harmel, R.D., Veith, T.L., 2007. Model evaluation guidelines for systematic quantification of accuracy in watershed simulations. Trans. ASABE 50, 885-900.

Murray-Hudson, M., Wolski, P., Cassidy, L., Brown, M.T., Thito, K., Kashe, K., Mosimanyana, E., 2015. Remote sensing-derived hydroperiod as a predictor of floodplain vegetation composition. Wetlands Ecol. Manage. 23, 603-616.

Murray-Hudson, M., Wolski, P., Murray-Hudson, F., Brown, M.T., Kashe, K., 2014. Disaggregating hydroperiod: components of the seasonal flood pulse as drivers of plant species distribution in floodplains of a tropical wetland. Wetlands 34, 927942.

Murray, O., Thoms, M., Rayburg, S., 2006. The diversity of inundated areas in semiarid floodplain ecosystems. In: Rowan, J.S., Duck, R.W., Werritty, A. (Eds.), Sediment Dynamics and the Hydromorphology of Fluvial Systems. IAHS Press, Wallingford, UK.

Porter, J.L., Kingsford, R.T., Brock, M.A., 2007. Seed banks in arid wetlands with contrasting flooding, salinity and turbidity regimes. Plant Ecol. 188, 215-234.

Puckridge, J.T., Costelloe, J.F., Reid, J.R.W., 2010. Ecological responses to variable water regimes in arid-zone wetlands: coongie Lakes, Australia. Mar. Freshwater Res. 61, 832-841.

Ralph, T.J., Hesse, P.P., 2010. Downstream hydrogeomorphic changes along the Macquarie River, southeastern Australia, leading to channel breakdown and floodplain wetlands. Geomorphology 118, 48-64.

Ren, S., Kingsford, R.T., 2011. Statistically integrated flow and flood modelling compared to hydrologically integrated quantity and quality model for annual flows in the regulated Macquarie river in arid Australia. Environ. Manage. 48, 177-188.

Riccardi, G., 2000. A cell model for hydrological-hydraulic modeling. J. Environ. Hydrol. 8.

Roberts, J., Marston, F., 2011. Water Regime for Wetland and Floodplain Plants: a Source Book for the Murray-Darling Basin. National Water Commission, Canberra.

Rodríguez-Iturbe, I., Porporato, A., 2007. Ecohydrology of Water-Controlled Ecosystems: Soil Moisture and Plant Dynamics. Cambridge University Press.

Rodríguez, J.F., Saco, P.M., Sandi, S., Saintilan, N., Riccardi, G., 2017. Potential increase in coastal wetland vulnerability to sea-level rise suggested by considering hydrodynamic attenuation effects. Nature Commun. 8, 16094.

Rogers, K., 2011. Vegetation. In: Rogers, K., Ralph, T. (Eds.), Flodplain Wetland Biota in the Murray-Darling Basin: Water and Habitat Requirements. Australia.

Rogers, K., Ralph, T., Imgraben, S., 2010. Water requirements of biota, geomorphology and climate change in the Macquarie Marshes. In: Saintilan, N., Overton, I. (Eds.), Ecosystem Response Modelling in the Murray-Darling Basin. CSIRO Publishing, Melbourne.
Saco, P.M., Moreno-De Las Heras, M., Keesstra, S., Baartman, J., Yetemen, O., Rodríguez, J.F., 2018. Vegetation and soil degradation in drylands: non linear feedbacks and early warning signals. Curr. Opinion Environ. Sci. Health 5, 67-72.

Saco, P.M., Rodríguez, J.F., 2013. 2.14 Modeling ecogeomorphic systems. In: Shroder, J.F. (Ed.), Treatise on Geomorphology. Academic Press, San Diego.

Sandi-Rojas, S.G., Rodríguez, J.F., Saco, P., Riccardi, G., Wen, L., Saintilan, N., Stenta, H., Trivisonno, F., Basile, P.A., 2014. Macquarie river floodplain flow modeling: implications for ecogeomorphology. In: Schleiss, A.J., De Cesare, G., Franca, M.J., Pfister, M. (Eds.), River Flow 2014. CRC Press.

Sandi, S.G., Rodríguez, J.F., Saintilan, N., Riccardi, G., Saco, P.M., 2018. Rising tides, rising gates: the complex ecogeomorphic response of coastal wetlands to sea-level rise and human interventions. Adv. Water Res. 114, 135-148.

Sheldon, F., Bunn, S.E., Hughes, J.M., Arthington, A.H., Balcombe, S.R., Fellows, C.S., 2010. Ecological roles and threats to aquatic refugia in arid landscapes: dryland river waterholes. Mar. Freshwater Res. 61, 885-895.

Steinfeld, C.M.M., Kingsford, R.T., 2013. Disconnecting the floodplain: earthworks and their ecological effect on a dryland floodplain in the murray-darling basin, Australia. River Res. Appl. 29, 206-218.

Stenta, H.R., Riccardi, G.A., Basile, P.A., 2017. Grid size effects analysis and hydrological similarity of surface runoff in flatland basins. Hydrol. Sci. J. 62, 1736-1754.

Stromberg, J.C., Lite, S.J., Dixon, M.D., 2010. Effects of stream flow patterns on riparian vegetation of a semiarid river: implications for a changing climate. River Res. Appl. 26, 712-729.

Tan, Z., Jiang, J., 2016. Spatial-temporal dynamics of wetland vegetation related to water level fluctuations in Poyang Lake, China. Water 8, 397.

Tan, Z., Zhang, Q., Mengfan, L., Yunliang, L., Xiuli, X., Jiahu, J., 2016. A Study of the Relationship Between Wetland Vegetation Communities and Water Regimes using a Combined Remote Sensing and Hydraulic Modeling Approach.

Thomas, R., Bowen, S., Simpson, S., Cox, S., Sims, N., Hunter, S., Lu, Y., Saintilan, N., Overton, I., 2010. Inundation response of vegetation communities of the Macquarie Marshes in semi-arid Australia. Ecosystem Response Modelling in the Murray-Darling Basin. CSIRO Publishing, Melbourne.

Thomas, R.F., Kingsford, R.T., Lu, Y., Cox, S.J., Sims, N.C., Hunter, S.J., 2015. Mapping inundation in the heterogeneous floodplain wetlands of the Macquarie Marshes, using Landsat Thematic Mapper. J. Hydrol. 524, 194-213.

Thomas, R.F., Kingsford, R.T., Lu, Y., Hunter, S.J., 2011. Landsat mapping of annual inundation (1979-2006) of the Macquarie Marshes in semi-arid Australia. Int. J. Remote Sens. 32, 4545-4569.

Thoms, M.C., 2003. Floodplain-river ecosystems: lateral connections and the implications of human interference. Geomorphology 56, 335-349.

Thoms, M.C., Parsons, M., 2003. Identifying spatial and temporal patterns in the hydrological character of the Condamine-Balonne river, Australia, using multivariate statistics. River Res. Appl. 19, 443-457.

Tooth, S., McCarthy, T.S., 2007. Wetlands in drylands: geomorphological and sedimentological characteristics, with emphasis on examples from southern Africa. Prog. Phys. Geog. Earth Environ. 31, 3-41.

Wang, B., Chen, Y., Lü, C., 2015. Evaluating flood inundation impact on wetland vegetation FPAR of the Macquarie Marshes, Australia. Environ. Earth Sci. 74, 4989-5000.

Ward, J.V., Tockner, K., Schiemer, F., 1999. Biodiversity of floodplain river ecosystems: ecotones and connectivity1. Regulat. Rivers Res. Manag. 15, 125-139.

Wen, L., Ling, J., Saintilan, N., Rogers, K., 2009. An investigation of the hydrological requirements of River Red Gum (Eucalyptus camaldulensis) forest, using classification and regression tree modelling. Ecohydrology 2, 143-155.

Wen, L., MacDonald, R., Morrison, T., Hameed, T., Saintilan, N., Ling, J., 2013. From hydrodynamic to hydrological modelling: investigating long-term hydrological regimes of key wetlands in the Macquarie Marshes, a semi-arid lowland floodplain in Australia. J. Hydrol. 500, 45-61.

Wen, L., Saintilan, N., Rogers, K., Ling, J., 2010. Linking river red gum condition to hydrological change at Yanga National Park. In: Saintilan, N., Overton, I. (Eds.), Ecosystem Response Modelling in the Murray Darling Basin. CSIRO, Collingwood, Australia.

Wen, L., Yang, X., Saintilan, N., 2012. Local climate determines the NDVI-based primary productivity and flooding creates heterogeneity in semi-arid floodplain ecosystem. Ecol. Modell. 242, 116-126.

Whitaker, K., Rogers, K., Saintilan, N., Mazumder, D., Wen, L., Morrison, R.J., 2015. Vegetation persistence and carbon storage: implications for environmental water management for Phragmites Australis. Water Resour. Res. 51, 5284-5300.

Wilson, R., 1992. Vegetation Map of the Macquarie Marshes. NSW Department of Environment and Climate Change, Sydney.

Yonge, D., Hesse, P.P., 2009. Geomorphic environments, drainage breakdown, and channel and floodplain evolution on the lower Macquarie River, central-western New South Wales. Aust. J. Earth Sci. 56, 35-53. 